\title{
1 Subterranean Karst Environments as a Global Sink for Atmospheric Methane
}

3 Kevin D. Webster ${ }^{1,2}$, Agnieszka Drobniak ${ }^{3}$, Giuseppe Etiope ${ }^{4,5}$, Maria Mastalerz ${ }^{3}$,

$4 \quad$ Peter E. Sauer ${ }^{6}$ and Arndt Schimmelmann ${ }^{6}$

$6 \quad{ }^{1}$ School of Natural Resources and the Environment, University of Arizona, 1064 E Lowell St,

7 Tucson, Arizona 85721, USA

$8{ }^{2}$ Department of Ecology and Evolutionary Biology, University of Arizona, 1041 E Lowell St,

9 Tucson, Arizona 85721, USA.

$10{ }^{3}$ Indiana Geological Survey, Indiana University, 611 North Walnut Grove Ave., Bloomington,

11 Indiana 47405, USA.

12

${ }^{4}$ Istituto Nazionale di Geofisica e Vulcanologia, Sezione Roma 2, Italy.

$13{ }^{5}$ Faculty of Environmental Science and Engineering, Babes-Bolyai University, Cluj-Napoca,

14 Romania.

${ }^{6}$ Department of Earth and Atmospheric Sciences, Indiana University, $1001 \mathrm{E} 10^{\text {th }} \mathrm{St}$.

16 Bloomington, IN 47405, USA.

17

18 * corresponding author: kevdwebs@email.arizona.edu; telephone: 520-621-2539.

19 Keywords: cave; greenhouse gas; karst; methane; methanogenesis; methanotrophy 


\section{Abstract}

The air in subterranean karst cavities is often depleted in methane $\left(\mathrm{CH}_{4}\right)$ relative to the atmosphere. Karst is considered a potential sink for the atmospheric greenhouse gas $\mathrm{CH}_{4}$ because its subsurface drainage networks and solution-enlarged fractures facilitate atmospheric exchange. Karst landscapes cover about $14 \%$ of earth's continental surface, but observations of $\mathrm{CH}_{4}$ concentrations in cave air are limited to localized studies in Gibraltar, Spain, Indiana (USA), Vietnam, Australia, and by incomplete isotopic data. To test if karst is acting as a global $\mathrm{CH}_{4}$ sink, we measured the $\mathrm{CH}_{4}$ concentrations, $\delta^{13} \mathrm{C}_{\mathrm{CH}_{4}}$, and $\delta^{2} \mathrm{H}_{\mathrm{CH}_{4}}$ values of cave air from 33 caves in the USA and three caves in New Zealand. We also measured $\mathrm{CO}_{2}$ concentrations, $\delta^{13} \mathrm{C}_{\mathrm{CO}_{2}}$, and radon ( $\mathrm{Rn}$ ) concentrations to support $\mathrm{CH}_{4}$ data interpretation by assessing cave air residence times and mixing processes. Among these caves, 35 exhibited subatmospheric $\mathrm{CH}_{4}$ concentrations in at least one location compared to their local atmospheric backgrounds. $\mathrm{CH}_{4}$ concentrations, $\delta^{13} \mathrm{C}_{\mathrm{CH}_{4}}$, and $\delta^{2} \mathrm{H}_{\mathrm{CH}_{4}}$ values suggest that microbial methanotrophy within caves is the primary $\mathrm{CH}_{4}$ consumption mechanism. Only 5 locations from 3 caves showed elevated $\mathrm{CH}_{4}$ concentrations compared to the atmospheric background and could be ascribed to local $\mathrm{CH}_{4}$ sources from sewage and outgassing swamp water. Several associated $\delta^{13} \mathrm{C}_{\mathrm{CH}_{4}}$ and $\delta^{2} \mathrm{H}_{\mathrm{CH}_{4}}$ values point to carbonate reduction and acetate fermentation as biochemical pathways of limited methanogenesis in karst environments and suggest that these pathways occur in the environment over large spatial scales. Our data show that karst environments function as a global $\mathrm{CH}_{4}$ sink. 


\section{Introduction}

Atmospheric methane $\left(\mathrm{CH}_{4}\right)$ is a greenhouse gas and its concentration is increasing in the atmosphere (Dlugokencky et al., 2011; Sussmann et al., 2012; Ciais et al., 2013). The present globally averaged $\mathrm{CH}_{4}$ concentration is $1.87 \mathrm{ppmv}$ which is 2.5 times higher than preindustrial levels (Nisbet et al., 2016). The increase in atmospheric $\mathrm{CH}_{4}$ is due to an imbalance between $\mathrm{CH}_{4}$ sources and sinks. Anthropogenic and natural sources combine to contribute about $680 \mathrm{Tg} \mathrm{a}^{-1}$ of $\mathrm{CH}_{4}$ to the atmosphere while reactions with hydroxyl $(\cdot \mathrm{OH})$ and chlorine radicals in the troposphere and stratosphere remove about $600 \mathrm{Tg} \mathrm{a}^{-1}$ (Kirschke et al., 2013). Methanotrophic consumption in soils, the next largest sink, removes $30 \mathrm{Tg} \mathrm{a}^{-1}$ (Kirschke et al., 2013). Despite improvements in estimating individual sources and sinks of atmospheric $\mathrm{CH}_{4}$, the associated errors remain large (Kirschke et al., 2013). Recent studies suggest that caves may act as an additional $\mathrm{CH}_{4}$ sink (Mattey et al., 2013; Fernandez-Cortes et al., 2015; McDonough et al., 2016; Webster et al., 2016; Lennon et al., 2017).

Caves and associated karst landscapes may be an important overlooked sink for atmospheric $\mathrm{CH}_{4}$ because they are estimated to cover as much as 10 to $20 \%$ of the continental surface with more precise estimates suggesting about $13.8 \%$ (Palmer, 1991; Ford and Williams, 2007). Karst landscapes are frequently associated with the chemical dissolution of limestones, but can form in any soluble rock body. The resulting caves, solution-enlarged fractures, and internal drainage networks that function to transport mass from high elevations to low elevations also allow for subsurface-surface atmospheric exchange (Kowalczk and Froelich, 2010; Garcia-Anton et al., 2014). The total volume and surface area of karst conduits able to interact with the atmosphere is unknown, in part due to small fractures and the difficulty of imaging the subsurface with 
geophysical methods. Karst caves, due to their accessibility, provide opportunities for noninvasive, in-situ analyses and sampling.

Cave and karst landscapes form in two common ways, each of which influences karst's capacity to act as a $\mathrm{CH}_{4}$ sink. Epigenic karst forms through the interaction of limestone with carbonic acid derived from the dissolution of atmospheric and soil $\mathrm{CO}_{2}$ into surface waters. By contrast, hypogenic caves form when corrosive water from deep sources migrates into and dissolves limestone bedrock. Epigenic caves are more widespread, and atmospheric to subatmospheric $\mathrm{CH}_{4}$ concentrations of $1.8 \mathrm{ppmv}$ to $<0.1 \mathrm{ppmv}$ have been observed in these settings (Mattey et al., 2013; Fernandez-Cortes et al., 2015; McDonough et al., 2016; Webster et al., 2016; Lennon et al., 2017). For comparison, in some hypogenic caves elevated $\mathrm{CH}_{4}$ concentrations from 2 ppmv to $1 \%$ have been observed in association with $\mathrm{CH}_{4}$-rich springs or seeps related to fluid migration from deep hydrocarbon-bearing sedimentary rocks, i.e. seepage processes that are widespread on Earth (Sarbu et al., 1996; Hutchens et al., 2004; Jones et al., 2012; Webster et al., 2017). The dominance of epigenic karst suggests these regions are functioning as a $\mathrm{CH}_{4}$ sink at the global scale, but more observations are needed.

Different hypotheses have been put forward to explain the low $\mathrm{CH}_{4}$ concentrations observed in epigenic cave air. The combination of subatmospheric $\mathrm{CH}_{4}$ concentrations and the stable carbon isotopic ratio of $\mathrm{CH}_{4}$ in the air of caves in Gibraltar led to the hypothesis that microorganisms were responsible for the removal of $\mathrm{CH}_{4}$ (Mattey et al., 2013). In turn, low $\mathrm{CH}_{4}$ concentrations in Spanish caves, in the presumed absence of $\mathrm{CH}_{4}$-consuming (methanotrophic) bacteria, led to the hypothesis that $\mathrm{CH}_{4}$ oxidation was induced by ions and $\cdot \mathrm{OH}$ generated by the radioactive decay of radon and daughter nuclides (Fernandez-Cortes et al., 2015). Since these initial observations, datasets from caves in Australia, the USA, and Vietnam have pointed towards 
methanotrophic $\mathrm{CH}_{4}$ oxidation (McDonough et al., 2016; Webster et al., 2016; Lennon et al., 2017, Waring et al., 2017).

The chemical composition of cave air results from the mixing of the atmosphere and air from the overlying soils and epikarst. These processes should also influence the $\mathrm{CH}_{4}$ concentrations of cave air. Previous studies have shown that $\mathrm{CH}_{4}$ concentrations have been inversely correlated with $\mathrm{CO}_{2}$ concentrations in cave air (Mattey et al., 2013; Ferndandez-Cortes et al., 2015; McDonough et al., 2016; Webster et al., 2016). Cave air $\mathrm{CO}_{2}$ concentrations are positively correlated with radon $(\mathrm{Rn})$ concentrations and $\mathrm{Rn}$ is known to track cave air residence time (Cunningham and LaRock, 1991; Batiot-Guilhe et al., 2007; Kowalczk and Froelich, 2010; Mattey et al., 2010; Gregorič et al., 2011, 2014). Additionally, the stable C isotope composition of $\mathrm{CO}_{2}\left(\delta^{13} \mathrm{CCO}_{2}\right)$, can track the sources of $\mathrm{CO}_{2}$ in the environment. For example, $\delta^{13} \mathrm{CCO}_{2}$ values of $-24 \%$ are associated with soil $\mathrm{CO}_{2}$, while atmospheric $\mathrm{CO}_{2}$ has $\delta^{13} \mathrm{C}_{\mathrm{CO}_{2}}$ values ranging from -8.5 \%o to $-10 \%$ (Amundson et al., 1998; Keeling et al., 2010; Peyraube et al., 2013). Thus $\mathrm{CO}_{2}, \mathrm{Rn}$, and $\delta^{13} \mathrm{C}_{\mathrm{CO}_{2}}$ in cave air can help determine the influence of cave air mixing processes on $\mathrm{CH}_{4}$.

The stable $\mathrm{C}$ and $\mathrm{H}$ isotope compositions of $\mathrm{CH}_{4}\left(\delta^{13} \mathrm{C}_{\mathrm{CH}_{4}}\right.$ and $\left.\delta^{2} \mathrm{HCH}_{4}\right)$ also provide tools for understanding the sources and sinks of $\mathrm{CH}_{4}$ in caves because different $\mathrm{CH}_{4}$ sources are associated with characteristic $\delta^{13} \mathrm{C}_{\mathrm{CH}_{4}}$ and $\delta^{2} \mathrm{H}_{\mathrm{CH}_{4}}$ values. For example, $\mathrm{CH}_{4}$ produced from carbonate reduction has $\delta^{13} \mathrm{C}_{\mathrm{CH}_{4}}$ and $\delta^{2} \mathrm{H}_{\mathrm{CH}_{4}}$ values that range from -112 to $-60 \%$ VPDB and from -350 to $-100 \%$ VSMOW respectively (Whiticar, 1999). Atmospheric $\mathrm{CH}_{4}$ has $\delta^{13} \mathrm{C}_{\mathrm{CH}_{4}}$ and $\delta^{2} \mathrm{H}_{\mathrm{CH}_{4}}$ values around -47.5 and $-100 \%$ (Miller et al., 2002; Townsend-Small et al., 2012). The $\delta^{13} \mathrm{C}_{\mathrm{CH}_{4}}$ and $\delta^{2} \mathrm{H}_{\mathrm{CH}_{4}}$ values of $\mathrm{CH}_{4}$ can also be altered through secondary processes such as oxidation and mixing. The oxidation pathways of $\mathrm{CH}_{4}$ by methanotrophs or the $\mathrm{OH}$ have 
fractionation factors that cause the residual $\mathrm{CH}_{4}$ to show increases in $\delta^{2} \mathrm{H}_{\mathrm{CH}_{4}}$ values of $8.5 \%$ for every $1 \%$ increase in $\delta^{13} \mathrm{C}_{\mathrm{CH}_{4}}$ value and increases in $\delta^{2} \mathrm{H}_{\mathrm{CH}_{4}}$ values of $72 \%$ for every $1 \%$ increase

111 in $\delta^{13} \mathrm{C}_{\mathrm{CH}_{4}}$ value, respectively (Feisthauer et al., 2011; Saueressig et al., 2001). Mixing between

112 two different $\mathrm{CH}_{4}$ sources creates a linear trend between the two members. Thus, measuring the $113 \delta^{13} \mathrm{C}_{\mathrm{CH}_{4}}$ and $\delta^{2} \mathrm{H}_{\mathrm{CH}_{4}}$ of cave air should allow for the determination of cave air $\mathrm{CH}_{4}$ sources. that karst systems act as a $\mathrm{CH}_{4}$ sink on a global scale. To this aim, we studied $\mathrm{CH}_{4}$ concentrations,

$116 \delta^{13} \mathrm{C}_{\mathrm{CH}_{4}}$, and $\delta^{2} \mathrm{HCH}_{4}$ in cave air from 33 epigenic caves in the USA and three epigenic caves in 117 New Zealand. $\mathrm{CO}_{2}, \delta^{13} \mathrm{C}_{\mathrm{CO}_{2}}$, and $\mathrm{Rn}$ were also measured to support $\mathrm{CH}_{4}$ data interpretation via 118 assessing cave air residence times and mixing processes. Data analysis is focused on determining $119 \mathrm{CH}_{4}$ concentrations, origin, mixing processes and isotopic fractionations.

\section{Methods}

\subsection{Sampling and analyses}

Air samples from the study caves were collected over a timespan of roughly four years

124 (Fig. 1; Table 1). Study caves fell into three broad groups, those from the Appalachian fold and thrust belt (16); those in gently warped intracratonic basins of the USA (17); and those from the North Island of New Zealand (3). Cave air was sampled using in-situ and discrete methods. In-situ $\mathrm{CH}_{4}, \mathrm{CO}_{2}$, and $\mathrm{Rn}$ abundance analyses were carried out using a suite of instruments (Table 2).

128 Discrete samples of cave air were collected in pre-evacuated $50-\mathrm{mL}$ serum vials, in 1 to $3-\mathrm{L}$

129 Tedlar $^{\circledR}$ bags, or in $4-\mathrm{L}$ glass bottles. $\mathrm{CH}_{4}$ and $\mathrm{CO}_{2}$ concentrations of discrete samples were 130 measured via gas chromatography. 
We assessed cave air mixing processes through a variety of techniques. A qualitative

132 estimate on cave air residence time was obtained by comparing $\mathrm{CH}_{4}$ to $\mathrm{CO}_{2}$ concentrations at

133 individual locations in each cave. Additionally, we measured the Rn concentrations of caves 32

134 through 36 to assess the relationship between cave air residence time, $\mathrm{CH}_{4}$ concentrations, and

$135 \mathrm{CO}_{2}$ concentrations. $\delta^{13} \mathrm{CCO}_{2}$ data were used to assess the sources of $\mathrm{CO}_{2}$ and thus of air entering

136 the caves. We also assessed the distance from each sampling location to cave entrances as another 137 tool to understand cave air mixing processes.

$\mathrm{CH}_{4}$ and $\mathrm{CO}_{2}$ concentrations from discrete air samples were measured at Indiana University using a Varian 450 gas chromatograph (GC) (Varian - Agilent Technologies, Palo Alto,

140 California). The GC was fitted with a flame ionization detector (FID) for $\mathrm{CH}_{4}$ and a thermal 141 conductivity detector (TCD) for $\mathrm{CO}_{2}$. Standard gas mixtures from Air Liquide America Specialty

142 Gasses LLC (Plumsteadville, Pennsylvania) were used for 3-point calibration curves to convert 143 signals measured on the GC to concentrations. $\mathrm{CH}_{4}$ standards measured on the $\mathrm{GC}$ had errors of \pm 1445 to $\pm 14 \%$ of the reported concentrations. $\mathrm{CH}_{4}$ concentrations are reported with the uncertainty 145 associated with the standard curve unless the calculated uncertainty was $\leq 0.1 \mathrm{ppmv}$. Samples with 146 calculated uncertainties $\leq 0.1$ ppmv were assigned uncertainties of $0.1 \mathrm{ppmv}$ based on replicate 147 measurements. The uncertainty associated with standard curves for $\mathrm{CO}_{2}$ concentrations varied 148 from $< \pm 1$ to $5 \%$. $\mathrm{CO}_{2}$ concentrations were assigned uncertainties based on their associated 149 standard curve.

The stable carbon isotope ratios of $\mathrm{CH}_{4}$ and $\mathrm{CO}_{2}$ and hydrogen stable isotope ratios of $\mathrm{CH}_{4}$

151 were measured on a ThermoFinnigan Delta Plus XP mass spectrometer in the Stable Isotope

152 Research Facility at Indiana University. Carbon stable isotope ratios are expressed as conventional

$153 \delta^{13} \mathrm{C}_{\mathrm{CH}_{4}}$ and $\delta^{13} \mathrm{C}_{\mathrm{CO}_{2}}$ values in \%o along the scale anchored to Vienna Pee Dee Belemnite (VPDB). 
154 Hydrogen stable isotope ratios are expressed as $\delta^{2} \mathrm{H}_{\mathrm{CH}_{4}}$ values in \%o along the scale anchored to

155 Vienna Standard Mean Ocean Water (VSMOW). $\mathrm{CH}_{4}$ samples were measured in continuous-flow 156 mode using $\mathrm{CH}_{4}$ preconcentration, cryofocusing (Miller et al., 2002), and a gas chromatography157 oxidation/pyrolysis-isotope ratio mass spectrometer (GC-ox/pyr-IRMS) interface. Varying sample 158 extraction times were used to isolate roughly 0.45 and $0.90 \mu \mathrm{mol} \mathrm{of} \mathrm{CH}_{4}$ prior to the introduction 159 of the sample to the GC-ox/pyr-IRMS for analysis of $\delta^{13} \mathrm{C}_{\mathrm{CH}_{4}}$ and $\delta^{2} \mathrm{H}_{\mathrm{CH}_{4}}$ values, respectively. In160 house $\mathrm{CH}_{4}$ standards methane \#3, methane \#6, and methane ALM with $\delta^{13} \mathrm{C}_{\mathrm{CH}_{4}}$ and $\delta^{2} \mathrm{H}_{\mathrm{CH}_{4}}$ values 161 of $[+19.86 \pm 0.05 ;+2.2 \pm 1.2] \%$, $[-39.40 \pm 0.02 ;-153 \pm 2] \%$, and $[-58 \pm 1 ;-272.2 \pm 3.4] \%$ o

162 were used for 2-point normalizations. Errors associated with $\delta^{13} \mathrm{C}_{\mathrm{CH}_{4}}$ and $\delta^{2} \mathrm{H}_{\mathrm{CH}_{4}}$ values were 163 calculated using a standard curve that accounted for the peak size of the measurement. Analytical 164 repeatability of internal standards ranged from 0.14 to $0.6 \%$ for $\delta^{13} \mathrm{C}_{\mathrm{CH}_{4}}$ and from to 7 to $18 \%$ o 165 for $\delta^{2} \mathrm{HCH}_{4}$. $\delta^{13} \mathrm{C}_{\mathrm{CO}_{2}}$ values were measured in continuous-flow mode using a GasBench II inlet (Tu et al., 2001). Measured ${ }^{13} \mathrm{C} /{ }^{12} \mathrm{C}$ ratios of $\mathrm{CO}_{2}$ from cave air were converted to the VPDB scale using a single isotopically characterized in-house standard that has a value of $12.0 \pm 0.2 \%$.

\subsection{Data elaboration and quality control}

In-situ measurements were preferentially used when statistically analyzing gas

172 concentration data. When in-situ measurements were not available, concentrations measured on

173 the GC were used in the statistical analyses. Samples and data were screened for quality control

174 by comparing the samples with in-situ measurements and visual estimation of the volume of sample bags. If a sample bag had been shown to exhibit a leak for one analyte, data from that 
176

177

178

179

180

181

183

184

sample were discarded. $\mathrm{CH}_{4}$ and $\mathrm{CO}_{2}$ concentrations measured by both GC-FID and FTIR showed strong agreements $\left(\mathrm{GC}\left(\mathrm{CO}_{2}\right)=0.92 \pm 0.04 * \operatorname{FTIR}\left(\mathrm{CO}_{2}\right)+100 \pm 300, r^{2}=0.99, p=5 * 10^{-19}\right.$; $\left.\mathrm{GC}\left(\mathrm{CH}_{4}\right)=0.7 \pm 0.2 * \operatorname{FTIR}\left(\mathrm{CH}_{4}\right)+0.2 \pm 0.2, r^{2}=0.62\right)$, and the stable isotopic composition of the samples was not related to their storage time $\left(\delta^{13} \mathrm{C}_{\mathrm{CH}_{4}}=0.2 \pm 0.3 *\right.$ day $-47 \pm 2, r^{2}=0.03, p=$ $0.32 ; \delta^{2} \mathrm{HCH}_{4}=0.03 \pm 0.14 *$ day $-96 \pm 11, r^{2}=0.005, p=0.72 ; \delta^{13} \mathrm{CCO}_{2}=-0.05 \pm 0.16 *$ day $\left.-19.9 \pm 1.8, r^{2}=0.006, p=0.57\right)$. In locations where more than one sample was taken with insitu methods, the values of the samples were averaged. In total, $199 \mathrm{CH}_{4}$ concentrations, $192 \mathrm{CO}_{2}$ concentrations, $32 \delta^{13} \mathrm{C}_{\mathrm{CH}_{4}}$ values, $26 \delta^{2} \mathrm{HCH}_{4}$ values, and $60 \delta^{13} \mathrm{C}_{\mathrm{CO}_{2}}$ values are reported in this study (Supplemental Tables 1, 2). All samples are reported with $95 \%$ confidence intervals.

Three different modeling techniques were used to assess trace gas sources and sinks in the studied caves. Keeling plots of $\delta^{13} \mathrm{C}_{\mathrm{CH}_{4}}, \delta^{2} \mathrm{H}_{\mathrm{CH}_{4}}$, and $\delta^{13} \mathrm{C}_{\mathrm{CO}_{2}}$ were used to assess the possibility of a two end member mixing systems. The stable isotopic composition of $\mathrm{CO}_{2}$ entering the caves $\left(\delta^{13} \mathrm{C}_{\mathrm{s}}\right)$ was assessed through equation 1

$$
\delta^{13} \mathrm{C}_{\mathrm{s}}=\left(\delta^{13} \mathrm{C}_{\mathrm{m}}-F_{\mathrm{atm}} * \delta^{13} \mathrm{C}_{\mathrm{atm}}\right)\left(1-F_{\mathrm{atm}}\right)^{-1}
$$

where $\delta^{13} \mathrm{C}_{\mathrm{m}}$ is the $\delta^{13} \mathrm{C}_{\mathrm{CO}_{2}}$ of the sample, $\delta^{13} \mathrm{C}_{\mathrm{atm}}$ is the $\delta^{13} \mathrm{C}_{\mathrm{CO}_{2}}$ of the atmosphere, and $F_{\text {atm }}$ is the fraction of atmospheric $\mathrm{CO}_{2}$ in the $\mathrm{CO}_{2}$ concentration of the sample (Peyraube et al., 2016). We used values of $-10 \%$ for $\delta^{13} \mathrm{C}_{\text {atm }}$ and $400 \mathrm{ppmv}$ for the concentration of atmospheric $\mathrm{CO}_{2}$.

Rayleigh distillation models were used as the theoretical basis to examine changes in the stable isotopic composition of $\mathrm{CH}_{4}$ in cave air caused by methanotrophy or $\cdot \mathrm{OH}$ oxidation. The $\delta$ value of an isotope system in a chemical compound of interest (e.g., $\left.\mathrm{CH}_{4}\right)$ in cave air can be modeled as 


$$
\delta_{c}=\left(\delta_{i}+1000\right) f^{(-\alpha+1)}-1000
$$

198

199

200

201

202

203

204

205

206

207

208

209

where $\delta_{c}$ is the instantaneous $\delta$-value of a particular isotope system in cave air after partial consumption, $\delta_{i}$ is the initial $\delta$-value of the isotope system in cave air, $f$ is the fraction of the compound remaining, and $\alpha$ is the kinetic isotope fractionation factor (Mattey et al., 2013). $\alpha$ values of 1.018 and 1.1353 were used to model changes in $\delta^{13} \mathrm{C}_{\mathrm{CH}_{4}}$ and $\delta^{2} \mathrm{H}_{\mathrm{CH}_{4}}$ caused by methanotrophy (Coleman et al., 1981; Feisthauer et al., 2011). $\alpha$ values for changes in $\delta^{13} \mathrm{CCH}_{4}$ caused by methanotophy have been observed to range from 1.003 to 1.039 (Templeton et al., 2006; Feisthauer et al., 2011); 1.018 was selected based on observations of methanotrophy in soils and its similarity to the $\alpha$ value of 1.012 observed in St. Michael's Cave in Gibraltar (Feisthauer et al., 2011; Mattey et al., 2013). $\alpha$ values of 1.0039 and 1.294 were used to model changes in $\delta^{13} \mathrm{C}_{\mathrm{CH}_{4}}$ and $\delta^{2} \mathrm{H}_{\mathrm{CH}_{4}}$ values caused by $\cdot \mathrm{OH}$ oxidation (Saueressig et al., 2001). The initial stable isotopic composition of atmospheric $\mathrm{CH}_{4}$ was modeled with a $\delta^{13} \mathrm{C}_{\mathrm{CH}_{4}}=-47.5 \%$ (VPDB), and $\delta^{2} \mathrm{H}_{\mathrm{CH}_{4}}=$ $-100 \%$ (VSMOW) based on the work of Townsend-Small et al. (2012).

We examined the possibility of additional $\mathrm{CH}_{4}$ sources entering the cave systems through forward modeling. We assumed that two different sources of microbially produced $\mathrm{CH}_{4}$ contribute to cave air in addition to the atmosphere. We modeled $\mathrm{CH}_{4}$ produced from acetate fermentation as $\mathrm{S} 1\left(\delta^{13} \mathrm{C}_{\mathrm{CH}_{4}}=-49 \% \mathrm{VPDB}, \delta^{2} \mathrm{H}_{\mathrm{CH}_{4}}=-325 \%\right.$ VSMOW $)$ and from carbonate reduction as $\mathrm{S} 2$ $\left(\delta^{13} \mathrm{C}_{\mathrm{CH}_{4}}=-63 \%\right.$ VPDB, $\delta^{2} \mathrm{H}_{\mathrm{CH}_{4}}=-125 \%$ VSMOW) respectively (Whiticar, 1999; Etiope and Sherwood Lollar, 2013). These sources were mixed with cave air both prior to and after partial theoretical methanotrophic oxidation. Methanotrophic oxidation was modeled with the aforementioned $\alpha$ values of 1.018 and 1.1353 . 


\section{Results}

Each of the 36 caves showed atmospheric to subatmospheric $\mathrm{CH}_{4}$ concentrations in at least one location. Only five locations from three different caves showed elevated $\mathrm{CH}_{4}$ concentrations relative to the atmosphere (Fig. 2, Supplemental Table 1). The $\mathrm{CH}_{4}$ concentration in the atmosphere at study sites ranged from $1.8 \pm 0.3$ to $2.8 \pm 0.7$ ppmv. $\mathrm{CH}_{4}$ concentrations in cave air ranged from $\leq 0.1 \pm 0.1 \mathrm{ppmv}$ to $5 \pm 1 \mathrm{ppmv}$, and were generally observed to decrease with the distance from cave entrances (Fig. 3, Supplemental Table 1). Two thirds of the caves where three or more air measurements and distance data were recorded showed decreases in $\mathrm{CH}_{4}$ concentration from cave entrances to interiors. For example, caves 7, 8, and 9 from Kentucky all showed progressive decreases in $\mathrm{CH}_{4}$ concentration from about $2 \mathrm{ppmv}$ at the entrance of the cave, down to zero or near zero ppmv in the more inner rooms (from 2 to 0 in caves 8 and 9 and from 1.9 to 0.3 ppmv in cave 7). Additionally, $\mathrm{CH}_{4}$ concentrations were negatively correlated with $\mathrm{CO}_{2}$ concentrations in cave air following an inverse power law relationship $\left(\left[\mathrm{CH}_{4}\right]=17.5\left[\mathrm{CO}_{2}\right]^{-0.41}, r^{2}\right.$

$232=0.26$ ) (Fig. 2). In the caves where $\mathrm{Rn}$ concentrations were measured, the average $\mathrm{CO}_{2}$ 233 concentration of cave air was correlated with the average Rn concentration of cave air $\left(\left[\mathrm{CO}_{2}\right]=\right.$ $\left.234(1.42 \pm 0.09)[\mathrm{Rn}]+400 \pm 120, n=4, r^{2}=0.99, p=0.009\right)$.

Values of $\delta^{13} \mathrm{C}_{\mathrm{CO}_{2}}$ in cave air ranged from $-10.7 \pm 0.4$ to $-23.81 \pm 0.10 \%$. Analysis of $\delta^{13} \mathrm{C}_{\mathrm{CO}_{2}}$ values from samples with $\mathrm{CO}_{2}$ concentrations above $600 \mathrm{ppmv}$ showed that $\delta^{13} \mathrm{C}_{\mathrm{s}}$ ranging 237 from $-28 \%$ to $-20 \%$ contributed to the composition of $\mathrm{CO}_{2}$ in cave air. Pooled analysis of the $238 \mathrm{CO}_{2}$ dataset shows that the average apparent source $\delta^{13} \mathrm{C}_{\mathrm{CO}_{2}}$ value is $-23.3 \pm 0.5 \%{ }^{13} \delta_{\mathrm{CO}_{2}}=$ 239 $\left.4600\left[\mathrm{CO}_{2}\right]^{-1}-23.3 \pm 0.5 \%, r^{2}=0.83\right)($ Fig. 4$)$. 
$241-196 \pm 10$ to $+2 \pm 18 \%$, respectively. Keeling plots of $\delta^{13} \mathrm{C}_{\mathrm{CH}_{4}}$ did not suggest that a two end 242 member model was an adequate fit for the system $\left(\delta^{13} \mathrm{C}_{\mathrm{CH}_{4}}\right.$ vs. $[\mathrm{CH}]^{-1}: r^{2}=0.05, \delta^{2} \mathrm{HCH}_{4}$ vs.

$\left.243\left[\mathrm{CH}_{4}\right]^{-1}: r^{2}=0.12\right)$. Some cave air samples plotted near the theoretical relationship between $244 \delta^{13} \mathrm{C}_{\mathrm{CH}_{4}}$ values and $\mathrm{CH}_{4}$ concentrations caused by methanotrophy (Fig. 5). However, many points 245 fell below and to the left of the line representing the theoretical incomplete oxidation of 246 atmospheric $\mathrm{CH}_{4}$ (Figs. 5, 6). When $\delta^{2} \mathrm{H}_{\mathrm{CH}_{4}}$ and $\delta^{13} \mathrm{C}_{\mathrm{CH}_{4}}$ values were plotted against each other, 247 many samples clustered tightly near the signature of atmospheric $\mathrm{CH}_{4}$ (Fig. 7). Some points, like 248 those from caves 25 and 26, plotted near the expected trend of partial atmospheric $\mathrm{CH}_{4}$ oxidation 249 by methanotrophy. The modeled $\delta^{13} \mathrm{C}_{\mathrm{CH}_{4}}$ and $\delta^{2} \mathrm{H}_{\mathrm{CH}_{4}}$ values of cave air overlapped with our 250 collected samples (Figs. 5, 6, 7, Supplemental Table 3).

\section{Discussion}

\subsection{Subsurface-Surface Atmospheric Exchange}

The concentrations and stable isotopic compositions of $\mathrm{CH}_{4}, \mathrm{CO}_{2}$, and $\mathrm{Rn}$ in cave air overlapped and diverged from those of the atmosphere. This suggests that atmospheric and internal cave processes influenced the composition of cave air. The majority of cave air samples were depleted in $\mathrm{CH}_{4}$ and enriched in $\mathrm{CO}_{2}$ relative to the local atmosphere. This points to processes like in-situ $\mathrm{CH}_{4}$ oxidation and diffusion of air from the epikarst to decrease $\mathrm{CH}_{4}$ and increase $\mathrm{CO}_{2}$ concentrations (Fig. 2). Many study locations local atmospheric $\mathrm{CH}_{4}$ concentrations were above the globally averaged atmospheric background which may have been due to their proximity to roads or pastures with local $\mathrm{CH}_{4}$ sources (Gioli et al., 2012; Harper et al., 2014). 
The decreases in $\mathrm{CH}_{4}$ concentration in cave air were associated with increases in cave air residence time. $\mathrm{CH}_{4}$ concentrations were correlated with increases in the distance from a cave entrance, $\mathrm{CO}_{2}$ concentration, $\mathrm{Rn}$ concentration, and decreases in $\delta^{13} \mathrm{C}_{\mathrm{CO}_{2}}$ values (Figs. 2, 3). The relationship between the distance to a cave entrance and the residence time of air in a particular cave is multivariate and we observed departures from this trend in several caves. For example, caves 13 and 15 experienced fast airflow, cave air was flowing out of the entrance of cave 26, cave 24 has multiple entrances which likely result in multiple flow paths, in cave 20 the distance scale of the measurements may have been too small to observe a decrease in $\mathrm{CH}_{4}$ concentration, and internal $\mathrm{CH}_{4}$ sources, which were present in cave 9, may obscure the relationship.

The concentration of $\mathrm{Rn}$ in cave air is known to track cave air residence time and has been observed to correlate with $\mathrm{CO}_{2}$ concentrations. We observed correlations between cave air $\mathrm{CO}_{2}$ and $\mathrm{Rn}$ concentrations. This matches other observations from the literature (Kowalczk and Froelich, 2010; Gregorič et al., 2011; as well as others). $\mathrm{CO}_{2}$ concentrations were negatively correlated with $\mathrm{CH}_{4}$ concentrations. This provides strong evidence that $\mathrm{CH}_{4}$ concentrations decreased with cave air residence time. Additionally, the $\delta^{13} \mathrm{C}_{\mathrm{CO}_{2}}$ values exhibited a continuum between atmospheric values of $-10 \%$ at low concentrations and decreased as $\mathrm{CO}_{2}$ concentrations increased. The projected $\delta^{13} \mathrm{C}_{s}$ values ranged from -28 to $-20 \%$ with an average $\delta^{13} \mathrm{C}_{\mathrm{CO}_{2}}$ value of $-23.3 \pm 0.5 \%$ entering the caves. This matches the $\delta^{13} \mathrm{C}_{\mathrm{CO}_{2}}$ of soils of $-24 \%$ (Amundson et al., 1998) (Fig. 4). It is possible that the observed source values that are more negative than $-24 \%$ may be due to dripwater degassing or fast airflow (Spötl et al., 2005; Garcia-Anton et al., 2014). The $\delta^{13} \mathrm{C}_{s}$ values that are more positive than $-24 \%$ may be caused by differential abundances of $\mathrm{C} 3$ and $\mathrm{C} 4$ plants above the caves (Breecker et al., 2012). Our $\mathrm{CO}_{2}$ data show that cave air 
284 residence time increased as the $\mathrm{CH}_{4}$ concentrations and $\delta^{13} \mathrm{C}_{\mathrm{CO}_{2}}$ values of cave air decreased, and 285 that the caves in our study are not atypical compared to other caves in the literature.

In some of the caves where we measured Rn concentrations, cave air flow was relatively 287 fast. The average $\mathrm{CO}_{2}$ and $\mathrm{Rn}$ concentrations from these caves were relatively low (cave 33, $\left[\mathrm{CO}_{2}\right]$ $288=540 \pm 20 \mathrm{ppmv},[\mathrm{Rn}]=20 \pm 100 \mathrm{~Bq} \mathrm{~m}^{-3}$; cave $34,\left[\mathrm{CO}_{2}\right]=560 \pm 30 \mathrm{ppmv},[\mathrm{Rn}]=200 \pm 400$

$289 \mathrm{~Bq} \mathrm{~m}^{-3}$ ). Despite the similarity to atmospheric $\mathrm{CO}_{2}$ concentrations in these caves, average $\mathrm{CH}_{4}$ 290 concentrations were still depleted relative to the atmosphere (cave 33, $\left[\mathrm{CH}_{4}\right]=1.07 \pm 0.06 \mathrm{ppmv}$; 291 cave 34, $\left[\mathrm{CH}_{4}\right]=1.34 \pm 0.06 \mathrm{ppmv}$ ). These observations show that an in-situ process is removing $292 \mathrm{CH}_{4}$ from the cave air because subatmospheric $\mathrm{CH}_{4}$ concentrations in cave air are still observed in 293 the absence of large increases in $\mathrm{CO}_{2}$ concentrations as would be expected if $\mathrm{CH}_{4}$ were only diluted 294 by the arrival of $\mathrm{CH}_{4}$-free air into caves from soils. These observations agree with other 295 observations of fast $\mathrm{CH}_{4}$ oxidation in caves (Fernandez-Cortes et al., 2015; Lennon et al., 2017; 296 Warring et al., 2017). Landscape scale $\mathrm{CH}_{4}$ flux data from karst areas are needed to estimate the 297 size of the karst sink.

\subsection{Sources and Stable Isotopic Composition of Methane}

Our $\mathrm{CH}_{4}$ concentration, $\delta^{13} \mathrm{C}_{\mathrm{CH}_{4}}$, and $\delta^{2} \mathrm{H}_{\mathrm{CH}_{4}}$ data from caves show that caves have sources

301 of non-atmospheric $\mathrm{CH}_{4}$. Additional sources of $\mathrm{CH}_{4}$ entering caves were detected by $\mathrm{CH}_{4}$ 302 concentrations above the atmospheric background in three caves, namely (i) cave 3, Indiana, (ii) cave 22, Tennessee, and (iii) cave 32, New Zealand. Caves with $\mathrm{CH}_{4}$ concentrations above the 304 atmospheric background appear to be uncommon, and understanding if there is a systematic 305 change in karst landscapes from lower order to higher order drainages awaits future work. 
The departures of $\delta^{13} \mathrm{C}_{\mathrm{CH}_{4}}$ and $\delta^{2} \mathrm{H}_{\mathrm{CH}_{4}}$ values from the theoretical oxidations lines of

307 atmospheric $\mathrm{CH}_{4}$ show that caves have non-atmospheric $\mathrm{CH}_{4}$ sources. Our data point to the 308 methanogenic sources of acetate fermentation and carbonate reduction (Fig. 7). Other studies have 309 also shown microbially produced $\mathrm{CH}_{4}$ entering caves (Mattey et al., 2013; Webster et al., 2016).

310 Mixing between residual atmospheric $\mathrm{CH}_{4}$ from partial methanotophic oxidation and $\mathrm{CH}_{4}$ from 311 acetate fermentation in the soil-epikarst-cave system will generally cause a decrease in the $\delta^{13} \mathrm{C}_{\mathrm{CH}_{4}}$ 312 and $\delta^{2} \mathrm{H}_{\mathrm{CH}_{4}}$ values of cave air compared to the oxidation of atmospheric $\mathrm{CH}_{4}$, and this is supported 313 by our modeling (Figs. 5, 6). For example, caves 23, 24, and 26 all appear to be influenced by 314 acetoclastic methanogenesis.

$\mathrm{CH}_{4}$ produced from carbonate reduction is inferred to enter the caves based on samples that had $\delta^{2} \mathrm{H}_{\mathrm{CH}_{4}}$ values that were roughly equal to, or more positive than atmospheric values (Fig. 7).

317 The stable isotopic compositions of $\mathrm{CH}_{4}$ from caves 5, 15, 25, and 27 can be explained by partial methanotrophic consumption of $\mathrm{CH}_{4}$ generated from carbonate reduction with the strongest source signal in cave 5 (Fig. 7). $\mathrm{CO}_{2}$ reduction is typically observed in lake sediments, but has been observed in oxidizing environments such as biological soil crusts in deserts after rain events (Angel et al., 2011). We hypothesize that karst environments, which are less oxidizing, exhibit similar behavior. Our data show that carbonate reduction and acetate fermentation can occur in similar environments over large spatial scales and are not limited to aquatic and arctic environments.

Sites of methanogenesis in or near the studied cave systems may include waterlogged soils above caves, cave soils themselves, and the epikarst. It is possible that after rain events anoxic micro niches occur in soil, or the epikarst and the generated $\mathrm{CH}_{4}$ is dissolved and later introduced into caves with drip waters. We confirmed that dissolved $\mathrm{CH}_{4}$ outgasses in drip water of cave 32, 
measuring increased $\mathrm{CH}_{4}$ concentrations in its vicinity. We confirmed that in-situ $\mathrm{CH}_{4}$ production can take place in locally anoxic environments within caves by measuring $\mathrm{CH}_{4}$ concentrations close to a bat guano deposit in cave 25 , Tennessee ( site $4 \mathrm{~h}$; average $\mathrm{CH}_{4}$ concentration $=0.3 \pm 0.5 \mathrm{ppmv}$ ). Time series measurements near the large bat guano deposit showed that $\mathrm{CH}_{4}$ concentrations oscillated between 0.5 ppmv and 0.1 ppmv over the course of seconds, presumably in response to episodic migration of $\mathrm{CH}_{4}$ bubbles through the moist guano (similar oscillations in ammonia, $\mathrm{NH}_{3}$, were also observed). Additionally, we observed circumstantial evidence for local in-situ $\mathrm{CH}_{4}$ production in cave 3 because measured $\mathrm{CH}_{4}$ concentrations upstream of a restroom in the cave were low, while measured $\mathrm{CH}_{4}$ concentrations downstream of the restroom were enhanced. Our data show that caves are capable of expressing elevated $\mathrm{CH}_{4}$ concentrations due to in-situ $\mathrm{CH}_{4}$ production when accumulations of organic matter, such as guano or plant material, foster methanogenesis or when dissolved $\mathrm{CH}_{4}$ from waters outgasses into cave air.

We observed minor amounts of thermogenic $\mathrm{CH}_{4}$ entering in at least one cave. Locally elevated $\mathrm{CH}_{4}$ concentrations in cave 9 (Mammoth Cave, Kentucky) were associated with a known hydrocarbon seep that is also transporting sulfide (Olson, 2013). Elevated $\mathrm{CH}_{4}$ concentrations, thought to derive from thermogenic $\mathrm{CH}_{4}$, have also been observed at sulfidic springs in Cueva de Villa Luz (Webster et al., 2017). Some $\delta^{13} \mathrm{C}_{\mathrm{CH}_{4}}$ and $\delta^{2} \mathrm{H}_{\mathrm{CH}_{4}}$ values in cave air, i.e. two of the samples from cave 24, are compatible with thermogenic $\mathrm{CH}_{4}$ isotopic signatures (e.g., Schoell, 1988; Etiope et al., 2009; Fig. 7). It cannot be excluded that small fluxes of $\mathrm{CH}_{4}$ from shales or hydrocarbon deposits underlying the limestone are entering caves through natural fractures, but our present isotope data cannot confirm this source for cave 24. The Antes and Utica shales, which contain hydrocarbon gases, are stratigraphically below cave 24 (Coleman et al., 2014), and geologic faults and joints, which are often aligned with caves, may serve as conduits for the flow 
of hydrocarbons (Powell, 1969). A confirmation of hydrocarbons entering from deep sources may be obtained through measurements of 'radiocarbon-dead' $\mathrm{CO}_{2}, \mathrm{Rn}$, and ethane.

\subsection{Methane Oxidation Mechanisms}

The combination of $\delta^{13} \mathrm{C}_{\mathrm{CH}_{4}}$ and $\delta^{2} \mathrm{H}_{\mathrm{CH}_{4}}$ values allow for inferences to be made about the $\mathrm{CH}_{4}$ oxidizing reactions in karst environments. We distinguish between two scenarios with distinct sets of assumptions. Many isotopic compositions of $\mathrm{CH}_{4}$ in this study cannot be accounted for in a first scenario in which we assume that (i) $\mathrm{CH}_{4}$ enters the caves from the atmosphere, through acetate fermentation, and through carbonate reduction, and that (ii) $\mathrm{CH}_{4}$ is removed from cave air through reactions involving the $\cdot \mathrm{OH}$. Conversely, in a second scenario, if it is assumed that (i) sources of $\mathrm{CH}_{4}$ in cave air include the atmosphere, acetate fermentation, and carbonate reduction, and that (ii) $\mathrm{CH}_{4}$ is removed from cave air by methanotrophy, all of the points fall within the plausibility envelope of the model, suggesting that methanotrophy is the mechanism responsible for removing $\mathrm{CH}_{4}$ from cave air (Fig. 7). Consideration of an additional source of thermogenic $\mathrm{CH}_{4}$ (natural gas) from deep geologic sources enlarges the plausibility fields of both prior scenarios to encompass all of the data. Furthermore, the modeled isotopic composition of cave air, which has the same assumptions as the second scenario, overlays comparably with our data set.

Our $\delta^{13} \mathrm{C}_{\mathrm{CH}_{4}}$ and $\delta^{2} \mathrm{H}_{\mathrm{CH}_{4}}$ data also agree with observations of $\delta^{13} \mathrm{C}_{\mathrm{CH}_{4}}$ and $\delta^{2} \mathrm{H}_{\mathrm{CH}_{4}}$ from a cave in Indiana where it appeared that $\mathrm{CH}_{4}$ from both acetate fermentation and carbonate reduction influenced cave air geochemistry (Webster et al., 2016). Additionally, our data resemble an arctic system characterized by acetoclastic and hydrogenotrophic $\mathrm{CH}_{4}$ sources and methanotrophy (McCalley et al., 2014). Our isotopic evidence for in-situ microbial $\mathrm{CH}_{4}$ oxidation in caves is 
corroborated by recent results from in-situ mesocosm experiments in Vietnam where cave rocks with live microorganisms were shown to consume $\mathrm{CH}_{4}$ even in cases where surface soils were very thin to non-existent (Lennon et al., 2017; Nguyễn-Thuỳ et al., 2017).

\section{Conclusions}

1) $\mathrm{CH}_{4}$ consumption is the dominant process in karst landscapes. Subterranean karst air generally shows subatmospheric $\mathrm{CH}_{4}$ concentrations. $\mathrm{CH}_{4}$ and $\mathrm{CO}_{2}$ concentrations were negatively correlated in cave air showing that as the residence time of cave air increases the $\mathrm{CH}_{4}$ concentration of cave air decreases. $\mathrm{CH}_{4}$ concentrations decreased faster than increases in $\mathrm{CO}_{2}$ concentration in cave air demonstrating that an in-situ process is responsible for the removal of $\mathrm{CH}_{4}$ from cave air.

2) The stable isotopic composition of $\mathrm{CH}_{4}$ in studied caves suggests that $\mathrm{CH}_{4}$ is being oxidized by microbial methanotrophy. This evidence adds to reports that methanotrophy is the mechanism by which $\mathrm{CH}_{4}$ is rapidly removed in cave air (Mattey et al., 2013; McDonough et al., 2016; Webster et al., 2016; Lennon et al., 2017, Waring et al., 2017). The observations of sub-atmospheric $\mathrm{CH}_{4}$ concentrations in cave air from this and other studies show that karst is behaving as a global $\mathrm{CH}_{4}$ sink.

3) The stable isotopic composition of $\mathrm{CH}_{4}$ in the studied caves suggests that, in addition to atmospheric $\mathrm{CH}_{4}$, at least two additional $\mathrm{CH}_{4}$ sources are present in some caves. We suggest that the sources include $\mathrm{CH}_{4}$ produced from acetate fermentation and from $\mathrm{CO}_{2}$ reduction. These data corroborate recent findings of partially oxidized $\mathrm{CH}_{4}$ entering cave air from acetate fermentation and $\mathrm{CO}_{2}$ reduction in Indiana (Webster et al., 2016). These 
observations of $\mathrm{CH}_{4}$ production by acetate fermentation and carbonate reduction suggest that both processes happen over a wide scale in the environment.

\section{Acknowledgements}

This material is based upon work supported by the U.S. Department of Energy, Office of Science, Office of Basic Energy Sciences, Chemical Sciences, Geosciences, and Biosciences Division under Award Number DE-SC0006978. This study was partially funded by NASA ASTEP (Award \# NNX11AJ01G) and a National Speleological Society research grant. We thank J. Forsythe of Lost River Cave (cave 7) and R. S. Toomey III of Mammoth Cave National Park for granting access. Members of the Bloomington Indiana Grotto facilitated access to caves in Indiana. The Richard Blenz Nature Conservancy permitted access to cave 35. We thank M. Lefticariu and J. Hayden-Moore of Little Egypt Grotto in Carbondale, Illinois for providing assistance and access to gas sampling in cave 36 (SE Missouri). T.V. Royer in SPEA at Indiana University made analytical gas chromatography available. We are grateful for constructive comments from H.M. Stoll and three anonymous reviewers.

\section{References}

Amundson, R., Stern, L., Baisden, T., Wang, Y., 1998. The isotopic composition of soil and soilrespired $\mathrm{CO}_{2}$. Geoderma 82, 83-114. http://dx.doi.org/10.1016/S0016-7061(97)00098-0

Angel, R., Matthies D., Conrad, R., 2011. Activation of methanogenesis in arid biological soil crusts despite the presence of oxygen. PLoS ONE 6(5), e20453. $\underline{\text { http://dx.doi.org/10.1371/journal.pone.0020453 }}$ 
Batiot-Guilhe, C., Seidel, J.-L., Jourde, H., Hébrard, O., Bailly-Comte, V., 2007. Seasonal variations of $\mathrm{CO}_{2}$ and ${ }^{222} \mathrm{Rn}$ in a Mediterranean sinkhole - sping (Causse d'Aumelas, SE France). International Journal of Speleology 36(1), 51-56.

Breecker, D.O., Payne, A.E., Quade, J., Banner, J.L., Ball, C.E., Meyer, K.W., Cowan, B.D., 2012. The sources and sinks of $\mathrm{CO}_{2}$ in caves under mixed woodland and grassland vegetation. Geochimica et Cosmochimica Acta 96, 230-246. http://dx.doi.org/10.1016/j.gca.2012.08.023

Ciais, P., Sabine, C., Bala, G., Bopp, L., Brovkin, V., Canadell, J., Chhabra, A., DeFries, R., Galloway, J., Heimann, M., Jones, C., Le Quéré, C., Myneni, R.B., Piao, S., Thornton, P., 2013. Carbon and other biogeochemical cycles. In (Stocker, T.F., Qin, D., Plattner, G.-K., Tignor, M., Allen, S.K., Boschung, A., Nauels, A., Xia, Y., Bex, V., Midgley, P.M., eds.) Climate Change 2013: The Physical Science Basis. Contribution to Working Group I to the Fifth Assessment Report of the Intergovernmental Panel on Climate Change. Cambridge University Press, Cambridge, United Kingdom and New York, NY, USA.

Coleman D.D., Risatti J.B., Schoell M., 1981. Fractionation of carbon and hydrogen isotopes by methane-oxidizing bacteria. Geochimica et Cosmochimica Acta 45(7), 1033-1037. http://dx.doi.org/10.1016/0016-7037(81)90129-0

Coleman, J.L., Jr., Ryder, R.T., Milici, R.C., Brown, S., 2014. Overview of the potential and identified petroleum source rocks of the Appalachian Basin, Eastern United States. In (Ruppert, L.F., Ryder, R.T., eds.) Coal and Petroleum Resources in the Appalachian basin; Distribution, Geologic Framework, and Geochemical Character: U.S. Geological Survey Professional Paper 1708, http://dx.doi.org/10.3133/pp1708G.13 
Cunningham, K.I., LaRock, E.J., 1991. Recognition of microclimate zones through radon mapping, Lecheguilla Cave, Carlsbad Caverns National Park, New Mexico. Health Physics 61(4), 493-500.

Dlugokencky, E.J., Houweling, S., Bruhwiler, L., Masarie, K.A., Lang, P.M., Miller, J.B., Tans, P.P., 2003. Atmospheric methane levels off: Temporary pause or a new steady state? Geophysical Research Letters 30 (1992), http://dx.doi.org/10.1029/2003GL018126

Dlugokencky, E.J., Nisbet, E.G., Fisher, R., Lowry, D., 2011. Global atmospheric methane: budget changes, and dangers. Phil. Trans. R. Soc. A 369, 2058-2072. http://dx.doi.org/10.1098/rsta.2010.0341

Etiope G., Feyzullayev A., Baciu C.L., 2009. Terrestrial methane seeps and mud volcanoes: a global perspective of gas origin. Marine and Petroleum Geology 26, 333-344. http://dx.doi.org/10.1016/j.marpetgeo.2008.03.001

Feisthauer, S., Vogt, C., Modrzynski, J., Szlenkier, M., Krüger, M., Siegert, M., Richnow, H.-H., 2011. Different types of methane monooxygenases produce similar carbon and hydrogen isotope fraction patterns during methane oxidation. Geochimica et Cosmochimica Acta 75(5), 1173-1184. http://dx.doi.org/10.1016/j.gca.2010.12.006

Fernandez-Cortes, A., Cuezva, S., Alvarez-Gallego, M., Garcia-Anton, E., Pla C., Benavente, D., Jurado V., Saiz-Jimenez, C., Sanchez-Moral, S., 2015. Subterranean atmospheres may act as daily methane sinks. Nature Communications 6(7003). http://dx.doi.org/10.1038/ncomms8003

Garcia-Anton, E., Cuezva, S., Fernandez-Cortes, A., Benavente, D., Sanchez-Moral, S., 2014. Main drivers of diffusive and advective processes of $\mathrm{CO}_{2}$-gas exchange between a shallow 
462

463

464

465

466

467

468

469

470

471

472

473

474

475

476

477

478

479

480

481

vadose zone and the atmosphere. International Journal of Greenhouse Gas Control 21, 113 129. http://dx.doi.org/10.1016/j.ijggc.2013.12.006

Ford, D., Williams, P., 2007. Karst Hydrogeology and Geomorphology. John Wiley \& Sons Ltd, England.

Gioli, B., Toscano, P., Lugato, E., Matese, A., Migilietta, F., Zaldei, A., Vaccari, F.P., 2012. Methane and carbon dioxide fluxes and source partitioning in urban areas: The case study of Florence, Italy. Environmental Pollution 164, 125-131. http://dx.doi.org/10.1016/j.envpol.2012.01.019

Gregorič, A., Zidanšek, A., Vaupotič, J., 2011. Dependence of radon levels in Postojna Cave on outside air temperature. Natural Hazards and Earth System Sciences 11, 1523-1528. http://dx.doi.org/ 10.5194/nhess-11-1523-2011

Gregorič, A., Vaupotič, J., Šebela, S., 2014. The role of cave ventilation in governing cave air temperature and radon levels (Postojna Cave, Slovenia). International Journal of Climatology 34(5), 1488-1500. http://dx.doi.org/10.1002/joc.3778

Harper, L.A., Weaver, K.H., De Visscher, A., 2014. Dinitrogen and methane gas production during the anaerobic/anoxic decomposition of animal manure. Nutrient Cycling in Agroecosystems 100(1), 53-64. http://dx.doi.org/10.1007/s10705-014-9626-9

Hutchens, E., Radajewski, S., Dumont, M.G., McDonald, I.R., Murrell, J.C., 2004. Analysis of methanotrophic bacteria in Movile Cave by stable isotope probing. Environmental Microbiology 6(2), 111-120. http://dx.doi.org/10.1046/j.1462-2920.2003.00543.x 
482

483

484

485

486

487

488

489

490

491

492

493

494

495

496

497

498

499

500

501

502

503

Jones, D.S., Albrecht, H.L., Dawson, K.S., Schaperdoth, I., Freeman, K.H., Pi, Y., Pearson, A., Macalady, J.L., 2012. Community genomic analysis of an extremely acidophilic sulfur oxidizing biofilm. The ISME Journal 6, 158-170. http://dx.doi.org/10.1038/ismej.2011.75

Kirschke, S., Bousquet, P., Ciais, P., Saunois, M., Canadell, J.G., Dlugokencky, E.J., Bergamaschi, P., Bergmann, D., Blake, D.R., Bruhwiler, L., Cameron-Smith, P., Castaldi, S., Chevallier, F., Feng, L., Fraser, A., Heimann, M., Hodson, E.L., Houweling, S., Josse, B., Fraser, P.J., Krummel, P.B., Lamarque, J.-F., Langenfelds, R.L., Le Quéré, C., Naik, V., O’Doherty, S., Palmer, P.I., Pison, I., Plummer, D., Poulter, B., Prinn, R.G., Rigby, M., Ringeval, B., Santini, M., Schmidt, M., Schindell, D.T., Simpson, I.J., Spahni, R., Steele, L.P., Strode, S.A., Sudo, K., Szopa, S., van der Werf, G.R., Voulgarakis, A., van Weele, M., Weiss, R.F., Williams, J.E., Zeng, G., 2014. Three decades of global methane sources and sinks. Nature Geoscience 6, 812-8123.

Keeling, R.F., Piper, S.C., Bollenbacher, A.F., Walker, S.J., 2010. Monthly atmospheric ${ }^{13} \mathrm{C} /{ }^{12} \mathrm{C}$ isotopic ratios for 11 SIO stations. In Trends: A Compendium of Data on Global Change. Carbon Dioxide Information Analysis Center, Oak Ridge National Laboratory, U.S. Department of Energy, Oak Ridge, Tenn., U.S.A.

Kowalczk, A.J., Froelich, P.N., 2010. Cave air ventilation and $\mathrm{CO}_{2}$ outgassing by radon-222 monitoring: How fast do caves breathe? Earth and Planetary Science Letters 289, 209-219. $\underline{\text { http://dx.doi.org/10.1016/j.eps1.2009.11.010 }}$

Lennon, J.T., Nguyễn-Thùy, D., Phạm, T.M., Drobniak, A., Tạ, P.H., Phạm, N.Đ., Streil, T., Webster, K.D., Schimmelmann, A., 2017. Microbial contributions to subterranean methane sinks. Geobiology 15(2), 254-258. http://dx.doi.org/10.1111/gbi.12214 
504

505

506

507

508

509

510

511

512

513

514

Mattey, D.P., Fairchild, I.J., Atkinson, T.C., Latin, J.-P., Ainsworth, M., Durell, R., 2010. Seasonal microclimate control of calcite fabrics, stable isotopes and trace elements in modern speleothem from St. Michaels Cave, Gibraltar. In (Pedley, H.M., Rogerson, M. eds.) Tufas and Speleothems: Unravelling the Microbial and Physical Controls: Geological Society, London, Special Publications 336, 323-344. http://dx.doi.org/10.1144/SP336.17

Mattey, D.P., Fisher, R., Atkinson, T.C., Latin, J.-P., Durrell, R., Ainsworth, M., Lowry, D., Fairchild, I.J., 2013. Methane in underground air in Gibraltar karst. Earth and Planetary Science Letters 374, 71-80. http://dx.doi.org/10.1016/j.eps1.2013.05.011

McCalley, C.K., Woodcroft, B.J., Hodgkins, S.B., Wehr, R.A., Kim, E.-H., Mondav, R., Crill, P.M., Chanton, J.P., Rich, V.I., Tyson, G.W., Saleska, S.R., 2014. Methane dynamics regulated by microbial community response to permafrost thaw. Nature $514,478-481$. http://dx.doi.org/10.1038/nature13798

McDonough, L.K., Iverach, C.P., Beckman, S., Manfield, M., Rau, G.C., Baker, A., Kelly, B.F.J., 2016. Spatial variability of cave-air carbon dioxide and methane concentrations and isotopic compositions in a semi-arid karst environment. Environmental Earth Sciences 75(700), http://dx.doi.org/10.1007/s12665-016-5497-5

Miller, J.B., Mack, K.A., Dissly, R., White, J.W.C., Dlugokencky, E.J., Tans, P.P., 2002. Development of analytical methods and measurements of ${ }^{13} \mathrm{C} /{ }^{12} \mathrm{C}$ in atmospheric $\mathrm{CH}_{4}$ from the NOAA Climate Monitoring and Diagnostics Laboratory Global Air Sampling Network. 

Journal of Geophysical Research: Atmospheres 107(D13), ACH 11-1-ACH 11-15. http://dx.doi.org/10.1029/2001JD000630

Nisbet, E.G., Dlugokencky, E.J., Manning, M.R., Lowry, D., Fisher, R.E., France, J.L., Michel, M.E., Miller, J.B., White, W.J.C., Vaughn, B., Bousquet, P., Pyle, J.A., Warwick, N.J., Cain, M., Brownlow, R., Zazzeri, G., Lanoisellé, M., Manning, A.C., Gloor, E., Worthy, D.E.J., Brunke, E.-G., Labuschagne, C., Wolff, E.W., Ganesan, A.L., 2016. Rising atmospheric methane: 2007-2014 growth and isotopic shift. Global Biogeochemical Cycles 30, 1356-1370. http:///dx.doi.org/10.1002/2016GB005406

Nguyễn-Thuỳ, D., Schimmelmann, A., Nguyễn-Văn, H., Drobniak, A., Lennon, J.T., Tạ, P.H., Nguyễn, N.T.Á., (2017). Subterranean microbial oxidation of atmospheric methane in $\begin{array}{llll}\text { cavernous } & \text { karst. } & \text { Chemical }\end{array}$ https://doi.org/10.1016/j.chemgeo.2017.06.014

Olson, R., 2013. Potential effects of hydrogen sulfide and hydrocarbon seeps on Mammoth Cave ecosystems. Mammoth Cave Research Symposia. Paper 28. http://digitalcommons.wku.edu/mc_reserch_symp/10th_Research_Symposium_2013/Res earch Posters/28

Palmer, A.N., 1991. Origin and morphology of limestone caves. Geological Society of America Bulletin 103(1), 1-21. $\quad$ http://dx.doi.org/10.1130/0016$\underline{7606(1991) 103<0001: \text { OAMOLC }>2.3 . \mathrm{CO} ; 2}$

Peyraube, N., Lastennet, R., Denis, A., Malaurent, P., 2013. Estimation of epikarst air $P_{\mathrm{CO}_{2}}$ using measurements of water $\delta^{13} \mathrm{C}$ TDIC, cave air $P_{\mathrm{CO}_{2}}$ and $\delta^{13} \mathrm{C}_{\mathrm{CO}_{2}}$. Geochimica et Cosmochimica Acta 118, 1-17. http://dx.doi.org/10.1016/j.gca.2013.03.046 
Peyraube, N., Lastennet, R., Villanueva, J.D., Houillon, N., Malaurent, P., Denis, A., 2016. Effect of diurnal and seasonal temperature variation on Cussac cave ventilation using $\mathrm{CO}_{2}$ assessment. Theoretical and Applied Climatology, http://dx.doi.org/10.1007/s00704-016$\underline{1824-8}$

Powell, R.L. 1969. Base level, and climatic controls of karst groundwater zones in South-Central Indiana. Indiana Academy of Science, 281-291.

Sarbu, S.M., Kane, T.C., Kinkle, B.K., 1996. A chemoautotrophically based cave ecosystem. Science 272(5270), 1953-1955. http://dx.doi.org/10.1126/science.272.5270.1953

Saueressig, G., Crowley, J.N., Bergamaschi, P., Brühl, C., Brennikmeijer, C.A.M., Fischer, H., 2001. Carbon 13 and D kinetic isotope effects in the reactions of $\mathrm{CH} 4$ with $\mathrm{O}\left({ }^{1} \mathrm{D}\right)$ and $\mathrm{OH}$ : New laboratory measurements and their implications for the isotopic composition of stratospheric methane. Journal of Geophysical Research 106 (D19), 23127-23138. http://dx.doi.org/10.1029/2000JD000120

Schoell, M., 1988. Multiple origins of methane in the Earth, in Schoell, M. ed. Origins of Methane in the Earth. Chemical Geology 71, 1-10. http://dx.doi.org/10.1016/0009-2541(88)90101$\underline{5}$

Spötl, C., Fairchild, I.J., Tooth, A.F., 2005. Cave air control on dripwater geochemistry, Obir Caves (Austria): Implications for speleothem deposition in dynamically ventilated caves. Geochimica et Cosmochimica

Acta

69(10), 2451-2468. http://dx.doi.org/10.1016/j.gca.2004.12.009 
565

566

567

568

569

570

571

572

573

574

575

576

577

578

579

580

581

582

583

584

Sussman, R., Forster, F., Rettinger, M., Bousquet, P., 2012. Renewed methane increase for five years (2007-2011) observed by solar FTIR spectrometry. Atmospheric Chemistry and Physics 12, 4885-4891. http://dx.doi.org/10.5194/acp-12-4885-2012

Templeton, A., Chu, K.-H., Alvarez-Cohen, L., Conrad, M.E., 2006. Variable carbon isotope fractionation expressed by aerobic $\mathrm{CH}_{4}$-oxidizing bacteria. Geochimica et Cosmochimica Acta 70(7), 1739-1752. http://dx.doi.org/10.1016/j.gca.2005.12.002

Townsend-Small, A., Tyler, S.C., Pataki, D.E., Xu, X., Christensen, L.E., 2012. Isotopic measurements of atmospheric methane in Los Angeles, California, USA: Influence of "fugitive" fossil fuel emissions. Journal of Geophysical Research 117(D07308). http://dx.doi.org/10.1029/2011JD016826

Tu, K.P., Brooks, P.D., Dawson, T.E., 2001. Using septum-capped vials with continuous-flow isotope ratio mass spectrometric analysis of atmospheric $\mathrm{CO}_{2}$ for Keeling plot applications. Rapid Communications in Mass Spectrometry 15(12), 952-956. http://dx.doi.org/10.1002/rcm.320

Waring, C.L., Hankin, S.L., Griffith, D.W.T., Kertesz, M.A., Kobylski, V., Wilson, N.L., Coleman, N.V., Kettlewell, G., Zlot, R., Bosse, M., Bell, G., 2017. Scientific Reports 7(8314). http://dx.doi.org/10.1038/s41598-017-07769-6

Weary, D.J., Doctor, D.H., 2014. Karst in the United States: A digital map compilation and database: U.S. Geological Survey Open-File Report 2014-1156. $\underline{\text { http://dx.doi.org/10.3133/ofr20141156 }}$ 
585 Webster, K.D., Mirza, A., Deli, J.M., Sauer, P.E., Schimmelmann, A., 2016. Consumption of

586

587

588

589

590

591

592

593

594

595 atmospheric methane in a limestone cave in Indiana, USA. Chemical Geology 443, 1-9. http://dx.doi.org/10.1016/j.chemgeo.2016.09.020

Webster, K.D., Rosales Lagarde, L., Sauer, P.E., Schimmelmann, A., Lennon, J.T., Boston, P.J., 2017. Isotopic evidence for the migration of thermogenic methane into a sulfidic cave, Cueva de Villa Luz, Tabasco, Mexico. Journal of Cave and Karst Studies 79(1), 24-34. https://caves.org/pub/journal/PDF/V79/cave-79-01-24.pdf.

Whiticar, M.J., 1999. Carbon and hydrogen isotope systematics of bacterial formation and oxidation of methane. Chemical Geology 161, 291-314. http://dx.doi.org/10.1016/S0009$\underline{2541(99) 00092-3}$ 


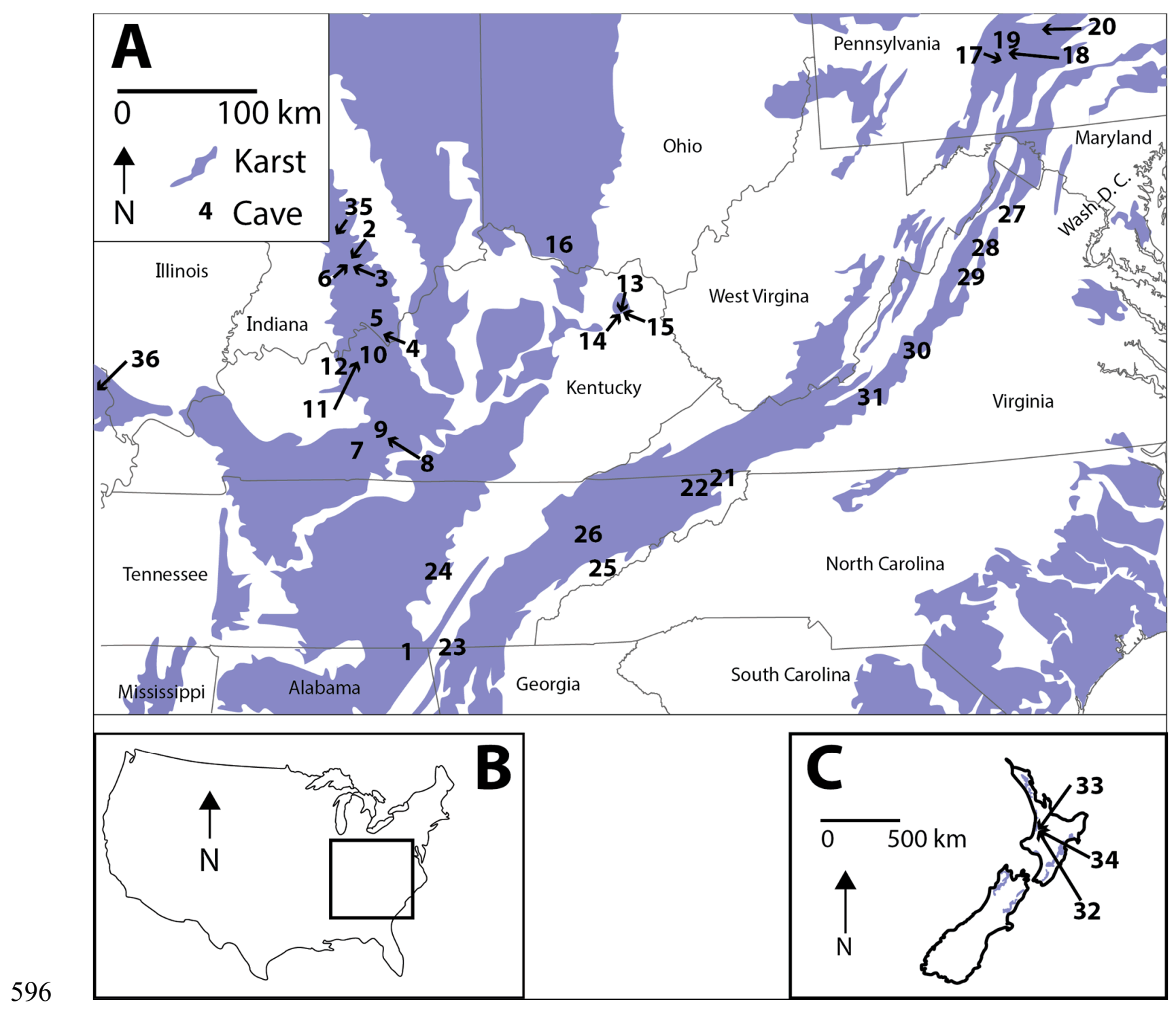

597 Figure 1. (A) Locations of the U.S. study caves in their regional context and (B) within the 598 contiguous USA. (C) The location of the New Zealand caves. Karst land cover data were obtained 599 from Weary and Doctor (2014) and Ford and Williams (2007).

600 


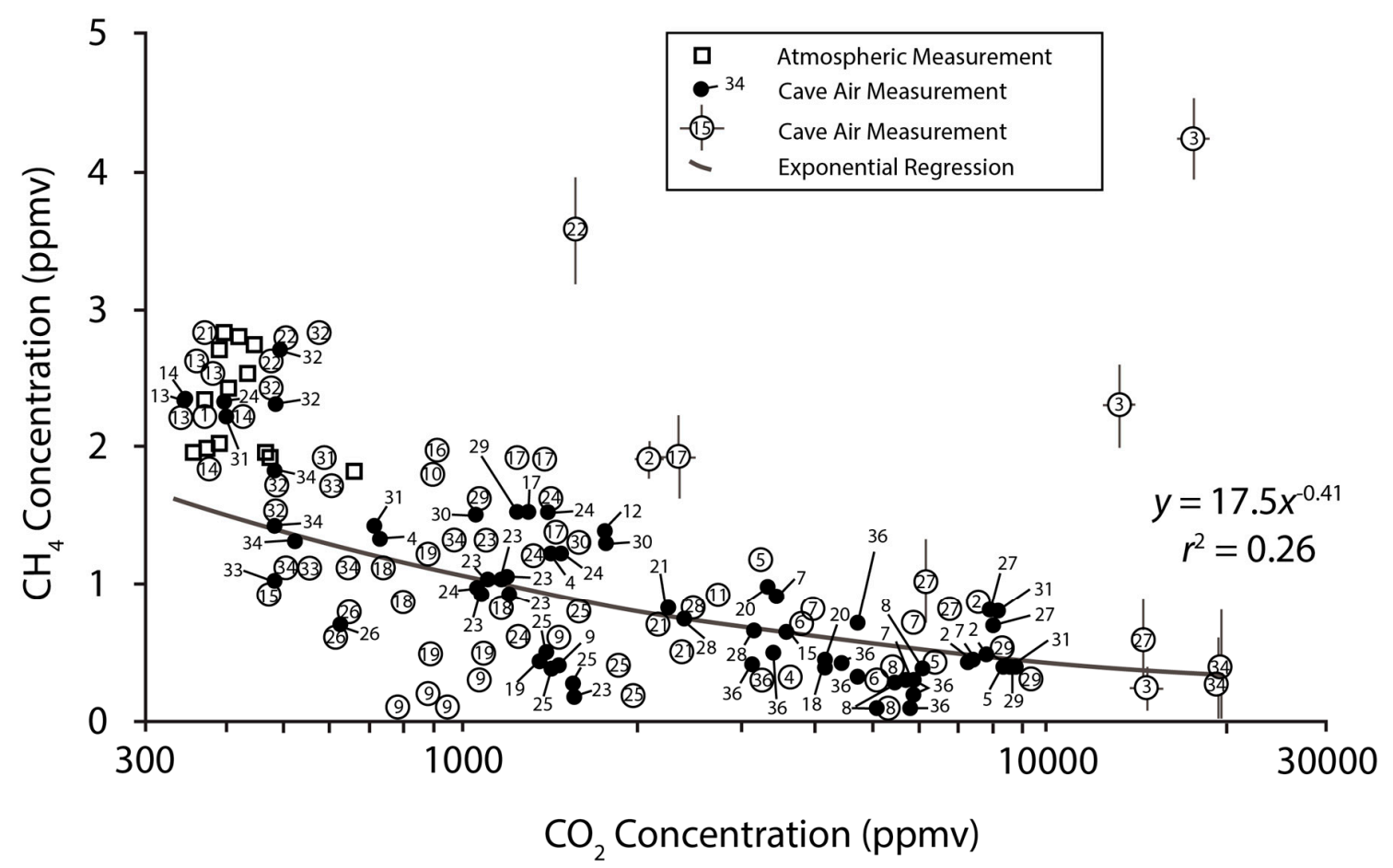

601

602 Figure 2. $\mathrm{CH}_{4}$ concentrations versus $\mathrm{CO}_{2}$ concentrations in studied caves. The majority of samples 603 appear to follow an inverse power law relationship with $\mathrm{CH}_{4}$ concentrations being inversely related 604 to $\mathrm{CO}_{2}$ concentrations (with points from caves 3 and 22 removed from the overall trend). Numbers 605 represent individual caves. For clarity, some points are shown as black dots with a line pointing to 606 the cave number of the sample. Some error bars were omitted from the figure for clarity. Data 607 associated with error bars are also representative for typical errors of data where no bars are shown. 
Cave 8, Kentucky

$\mathrm{CH}_{4}$ concentration in air

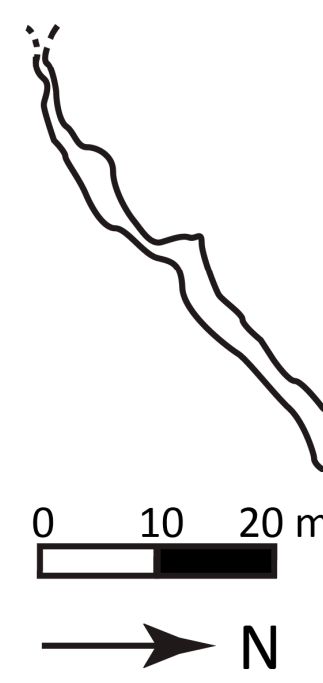

$\mathrm{I}=$ Inspectra

$\mathrm{G}=$ GasFinder2 is

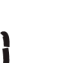

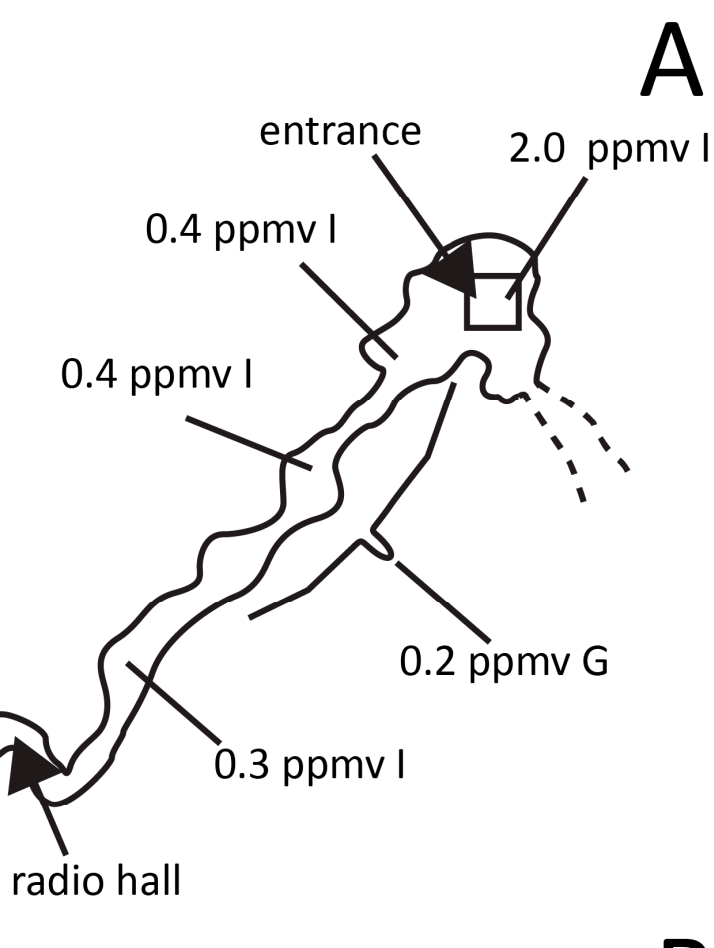

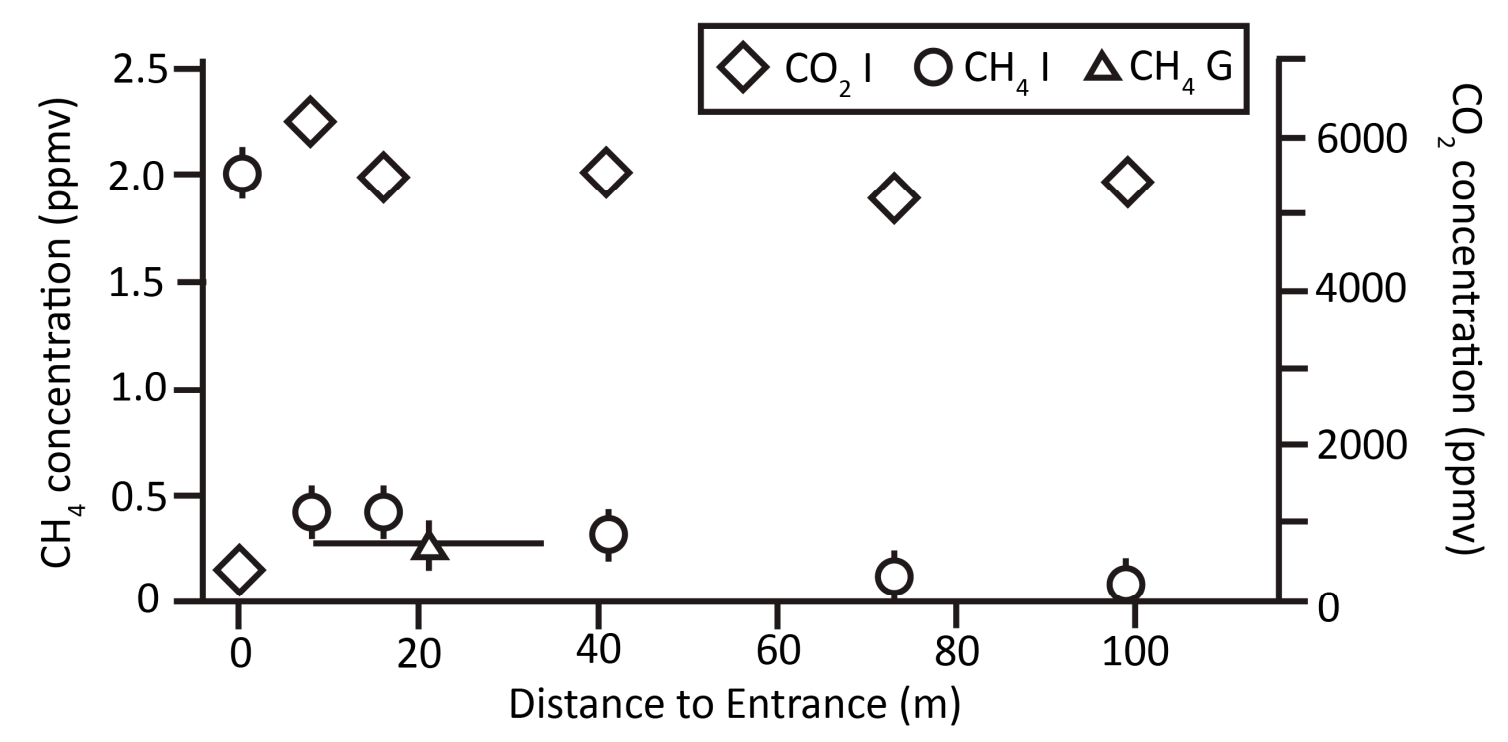

609

610 Figure 3. The spatial variation of $\mathrm{CH}_{4}$ mole faction in the air of cave 8, Kentucky sampled on May

6116 , 2012. (A) $\mathrm{CH}_{4}$ concentration dropped sharply down to $0.4 \mathrm{ppmv}$ along a narrow path after the

612 first large room, a few tens of meter from the entrance. $\mathrm{CH}_{4}$ gradually decreased over roughly 100 
$613 \mathrm{~m}$ down to $0 \mathrm{ppmv}$ in the Cathedral room, (B) while $\mathrm{CO}_{2}$ exhibited relatively constant 614 concentrations in cave air.

615

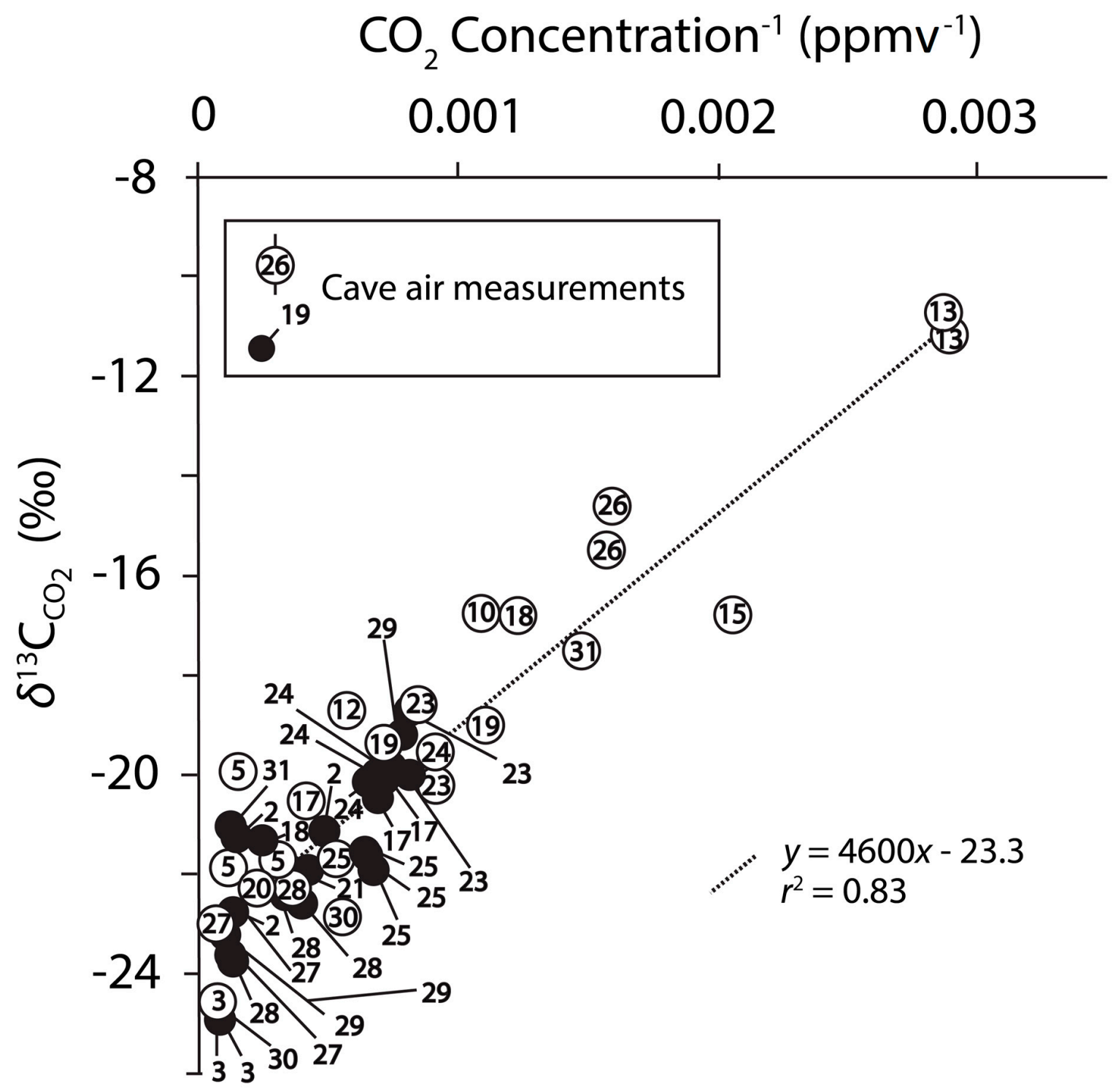

616

617 Figure 4. A Keeling plot of $\delta^{13} \mathrm{C}_{\mathrm{CO}_{2}}$ versus inverse $\mathrm{CO}_{2}$ concentration in cave air samples. The 618 data show that atmospheric $\mathrm{CO}_{2}$ is mixing with apparent isotopic endmembers between -33 and $619-20.4 \%$. A regression analysis of the entire data set shows that the average $\delta^{13} \mathrm{C}_{\mathrm{CO}_{2}}$ value entering 
620 the caves is $-23.3 \pm 0.5 \%$. Numbers represent individual caves. For clarity, some points are shown

621 as black dots with a line pointing to the cave number of the sample, nor are error bars included.

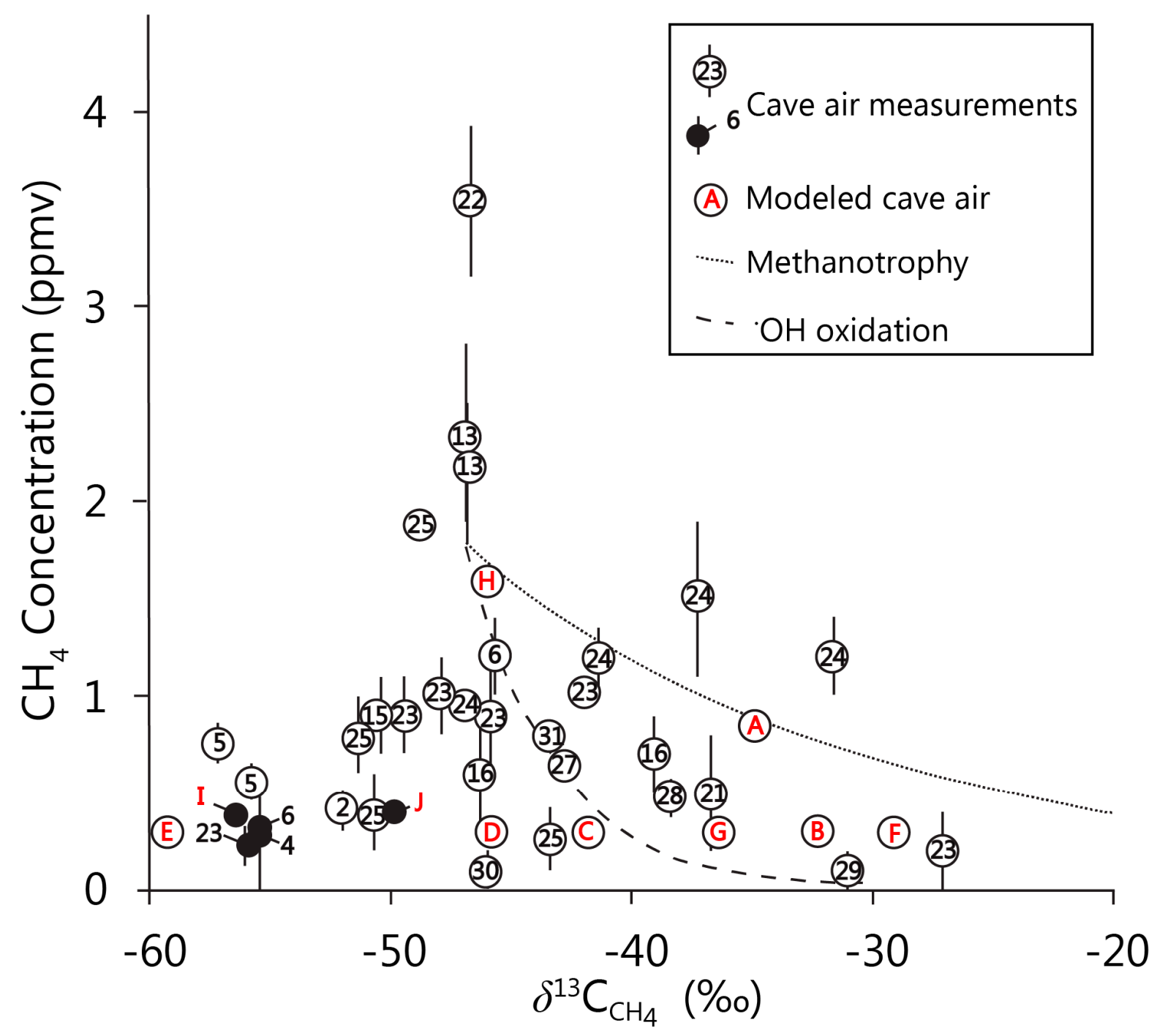

624 Figure 5. Relationship between $\mathrm{CH}_{4}$ concentration and $\delta^{13} \mathrm{C}_{\mathrm{CH}_{4}}$ in cave air. Some samples plot 625 along the expected relationship between $\mathrm{CH}_{4}$ concentration and $\delta^{13} \mathrm{C}_{\mathrm{CH}_{4}}$ caused either by 626 methanotrophy modeled with an $\alpha$ value of 1.018 , or by oxidation with $\cdot \mathrm{OH}$ modeled with an $\alpha$ 
627 value of 1.0039. Other samples plot below and to the left of the theoretical shifts of the oxidation

628 trends. Numbers represent individual caves. Note that modeled cave air, represented by letters,

629 also plots left of theoretical methanotrophic oxidation. For clarity, some points are shown as black

630 dots with a line pointing to the cave number of the sample. If error bars are not visible, they are

631 smaller than the data points.

632

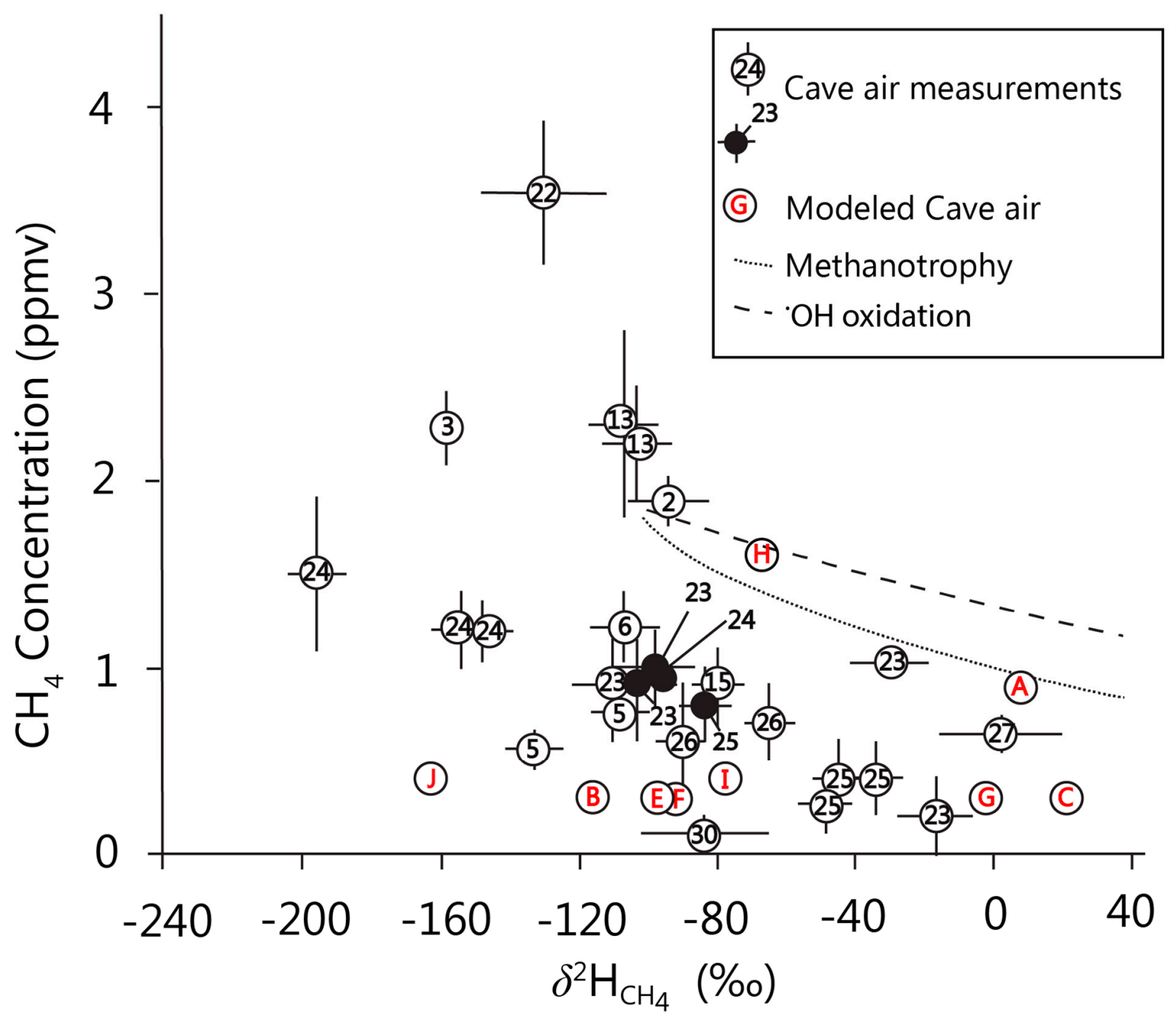


634 Figure 6. Relationship between methane concentration and $\delta^{2} \mathrm{H}_{\mathrm{CH}_{4}}$ in cave air. Some samples plot

635 along the expected relationship between $\mathrm{CH}_{4}$ concentration and $\delta^{2} \mathrm{H}_{\mathrm{CH}_{4}}$ caused by methanotrophy

636 modeled with an $\alpha$. value of 1.1353 , or by oxidation with $\cdot \mathrm{OH}$ modeled with an $\alpha$.value 1.294.

637 Other samples plot below and to the left of the shift caused by methanotrophy. Numbers represent

638 individual caves. Note that modeled cave air, represented by letters, generally plots left of the

639 theoretical oxidation lines. For clarity, some points are shown as black dots with a line pointing to

640 the number of the cave the sample is from. If error bars are not visible, they are smaller than the 641 data points. 


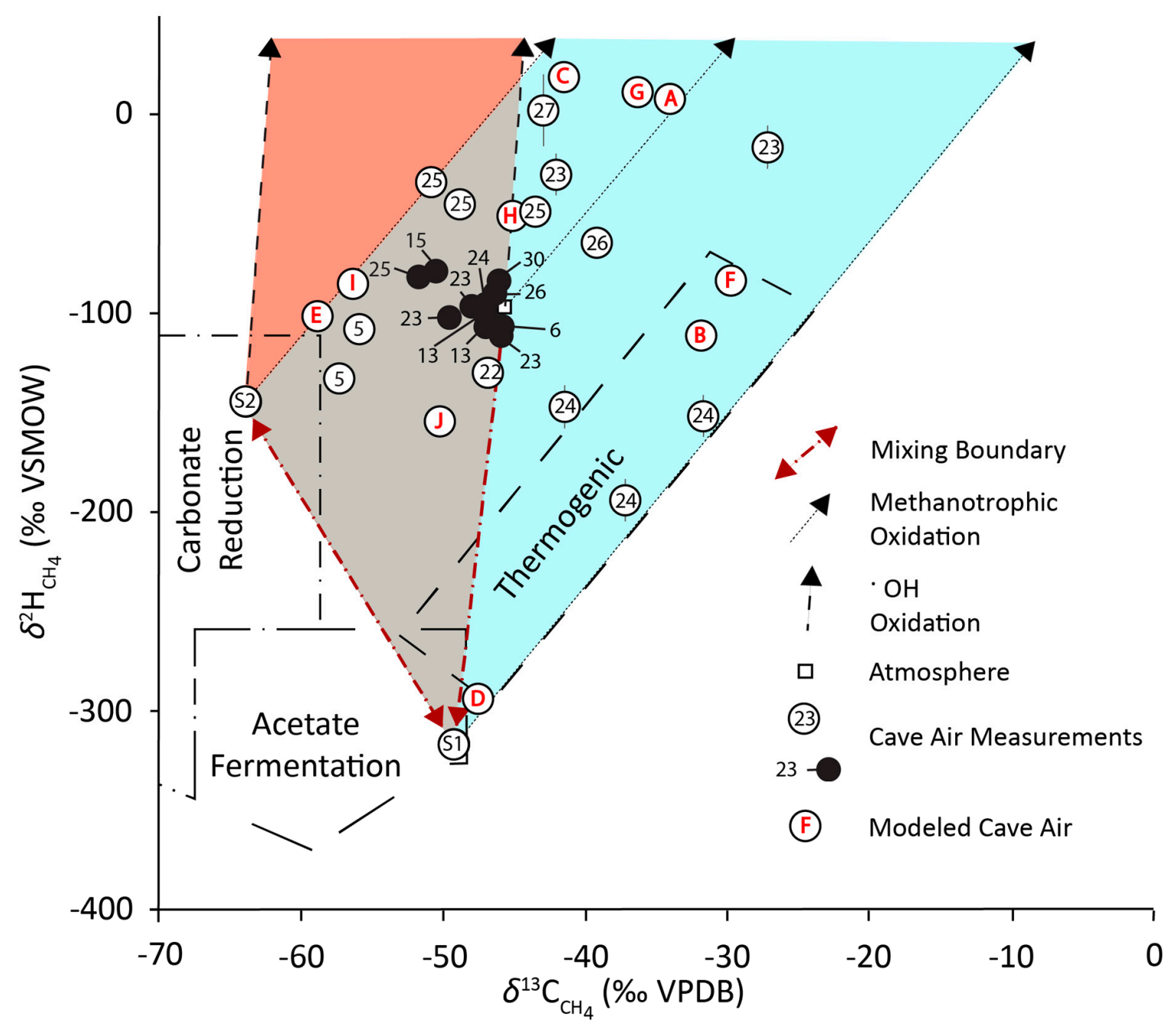

644 Figure 7. Stable isotopic composition of $\mathrm{CH}_{4}$ in cave air samples plotted in $\delta^{2} \mathrm{HCH}_{4}$ versus $\delta^{13} \mathrm{C}_{\mathrm{CH}_{4}}$

645 space. $\mathrm{CH}_{4}$ generated by carbonate reduction, acetate fermentation, and thermogenesis are plotted 646 within labeled fields (Whiticar, 1999). We model inputs from the atmosphere as $(-47.5 \%,-100$ $647 \%$, $\square)$, acetate fermentation as $(-49 \%,-325 \%$, S1), and carbonate reduction as $(-63 \%,-125$ $648 \%$, S2). Thin dotted lines indicate the expected shift in $\delta^{2} \mathrm{H}_{\mathrm{CH}_{4}}$ and $\delta^{13} \mathrm{C}_{\mathrm{CH}_{4}}$ caused by partial 649 aerobic methane oxidation adopting a slope of 8.5. Thick dashed lines indicate the expected shift 650 in $\delta^{2} \mathrm{H}_{\mathrm{CH}_{4}}$ and $\delta^{13} \mathrm{C}_{\mathrm{CH}_{4}}$ caused by oxidation with $\cdot \mathrm{OH}$ adopting a slope 75 (Saueressig et al., 2001;

651 Feisthauer et al., 2011). Mixing in $\delta^{2} \mathrm{HCH}_{4}$ vs $\delta^{13} \mathrm{C}_{\mathrm{CH}_{4}}$ space plots as a straight line, dark-red dot- 
652 dashed line. Numbers represent individual caves. Note the all of the data points can be described

653 by a source of $\mathrm{CH}_{4}$ from the atmosphere, a source from acetoclastic fermentation (S1), a source

654 from carbonate reduction (S2), mixing, and methanotrophic oxidation and do not plot within the

655 bounds of $\cdot \mathrm{OH}$ oxidization (gray and blue fields). For clarity, some points are shown as black dots

656 with a line pointing to the cave number of the sample. Error bars are not included with black circles

657 for clarity. In other locations, if error bars are not visible, they are smaller than the data points.

658

659 Table 1: Overview of collected data. 'Discrete' measurements refer to the laboratory.

\begin{tabular}{|c|c|c|c|c|c|c|c|c|}
\hline Cave & State & $\begin{array}{c}\text { Collection } \\
\text { date }^{\mathrm{a}}\end{array}$ & $\begin{array}{c}\text { Sites } \\
\text { measured }\end{array}$ & $\begin{array}{c}{\left[\mathrm{CH}_{4}\right] \min } \\
(\mathrm{ppmv})\end{array}$ & $\begin{array}{c}{\left[\mathrm{CH}_{4}\right] \max } \\
(\mathrm{ppmv})\end{array}$ & $\begin{array}{c}{\left[\mathrm{CO}_{2}\right] \mathrm{min}} \\
(\mathrm{ppmv})\end{array}$ & $\begin{array}{c}{\left[\mathrm{CO}_{2}\right] \max } \\
(\mathrm{ppmv})\end{array}$ & Methods \\
\hline 1 & $\mathrm{AL}$ & 2015-04-07 & 1 & $N A^{b}$ & 2.2 & NA & 378 & In-situ \\
\hline 2 & IN & 2013-08-10 & 4 & 0.42 & 1.89 & 2140 & 8000 & Discrete \\
\hline 3 & IN & 2013-08-07 & 3 & 0.23 & 4.2 & 13400 & 17900 & Discrete \\
\hline 4 & IN & 2013-06-18 & 2 & 0.3 & 0.7 & 3900 & 5200 & Discrete \\
\hline 5 & IN & 2013-06-29 & 3 & 0.4 & 1.18 & 3300 & 8600 & Discrete \\
\hline 6 & IN & 2013-06-14 & 3 & 0.32 & 1.32 & 750 & 3700 & Discrete \\
\hline 7 & KY & 2012-05-05 & 4 & 0.3 & 0.9 & 3500 & 6020 & In-situ \\
\hline 8 & KY & 2012-05-06 & 5 & 0.0 & 0.4 & 5200 & 6200 & In-situ \\
\hline 9 & KY & 2012-05-07 & 7 & 0.08 & 0.6 & 900 & 1500 & In-situ \\
\hline 10 & KY & 2013-07-18 & 1 & NA & 1.79 & NA & 920 & Discrete \\
\hline 11 & KY & 2013-07-18 & 1 & NA & 0.91 & NA & 2790 & Discrete \\
\hline 12 & KY & 2013-07-18 & 1 & NA & 1.37 & NA & 1790 & Discrete \\
\hline 13 & KY & 2015-04-10 & 4 & 2.3 & 2.6 & 349 & 390 & Mixed \\
\hline 14 & KY & 2015-04-10 & 3 & 1.82 & 2.33 & 351 & 390 & In-situ \\
\hline 15 & KY & 2015-04-10 & 2 & 0.9 & 1.8 & 440 & 486 & Mixed \\
\hline 16 & $\mathrm{OH}$ & 2015-04-10 & 1 & NA & 1.95 & NA & 940 & In-situ \\
\hline 17 & PA & 2013-07-15 & 5 & 1.4 & 1.9 & 1430 & 2400 & Mixed \\
\hline 18 & PA & 2013-07-15 & 4 & 0.4 & 1.1 & 760 & 4250 & Mixed \\
\hline 19 & PA & 2013-07-15 & 4 & 0.4 & 0.5 & 900 & 1400 & Mixed \\
\hline 20 & PA & 2013-07-16 & 3 & 0.4 & 1.0 & 3390 & 4240 & Mixed \\
\hline 21 & TN & 2013-07-18 & 3 & 0.5 & 1.25 & 2210 & 2430 & Mixed \\
\hline 22 & TN & 2013-07-19 & 3 & 2.6 & 3.5 & 490 & 1610 & Mixed \\
\hline 23 & $\mathrm{TN}$ & 2015-04-07 & 7 & 0.2 & 1.02 & 1100 & 1600 & Mixed \\
\hline 24 & $\mathrm{TN}$ & 2015-04-08 & 6 & 0.6 & 1.6 & 1100 & 1515 & Mixed \\
\hline 25 & TN & 2015-04-09 & 7 & 0.2 & 0.8 & 1430 & 2100 & Mixed \\
\hline 26 & $\mathrm{TN}$ & 2015-04-09 & 3 & 0.6 & 0.79 & 630 & 660 & Mixed \\
\hline
\end{tabular}


660

$\begin{array}{lll}27 & \text { VA } & 2015-07-17 \\ 28 & \text { VA } & 2015-07-17 \\ 29 & \text { VA } & 2015-07-17 \\ 30 & \text { VA } & 2015-07-18 \\ 31 & \text { VA } & 2015-07-18 \\ 32 & \text { NZ }^{c} & 2014-10-04 \\ 33 & \text { NZ } & 2014-10-04 \\ 34 & \text { NZ } & 2014-10-04 \\ 35 & \text { IN } & 2014-06-11 \\ 36 & \text { MO } & 2016-09-24\end{array}$

$0.6 \quad 1.0$

6300

14700

Mixed

$4 \quad 0.4$

0.8

2480

7600

Mixed

0.4

1100

8740

Mixed

1090

19900

Mixed

410

8900

Mixed

0.4

2.2

500

590

In-situ

1.0

500

620

In-situ

500

1000

In-situ

$N A^{d}$

$N A^{d}$

In-situ

0.14

2590

6190

In-situ

a Dates are formatted yyyy-mm-dd

${ }^{\mathrm{b}} \mathrm{NA}=$ not applicable where only 1 sample was obtained.

${ }^{\mathrm{c}} \mathrm{NZ}=$ New Zealand

${ }^{\mathrm{d}} \mathrm{NA}=$ Only $\mathrm{CH}_{4}$ was measured

661 Table 2: In-situ instrumentation used in this study.

\begin{tabular}{|c|c|c|c|c|c|}
\hline & & & \multicolumn{3}{|c|}{ Analytes } \\
\hline Instrument & Maker & Location & $\begin{array}{l}\text { Method } \\
\text { Tunable Diode }\end{array}$ & Measured & Lower detection limits \\
\hline GasFinder2 & $\begin{array}{l}\text { Boreal } \\
\text { Laser } \\
\text { Gazomat, } \\
\text { WEST }\end{array}$ & $\begin{array}{l}\text { Spruce Grove, } \\
\text { Alberta Canada }\end{array}$ & $\begin{array}{c}\text { Laser } \\
\text { Spectroscopy } \\
\text { Tunable Diode } \\
\text { Laser }\end{array}$ & $\mathrm{CH}_{4}$ & $1 \mathrm{ppmv} \mathrm{m}^{-1}$ \\
\hline Inspectra & Systems & Pontedera, Italy & $\begin{array}{l}\text { Spectroscopy } \\
\text { Tunable Diode }\end{array}$ & $\mathrm{CH}_{4}$ & $0.1 \mathrm{ppmv}$ \\
\hline LGD F200 & $\begin{array}{l}\text { Axetris, } \\
\text { SARAD }\end{array}$ & $\begin{array}{l}\text { Kägiswil, } \\
\text { Switzerland }\end{array}$ & $\begin{array}{c}\text { Laser } \\
\text { Spectroscopy } \\
\text { Tunable Diode }\end{array}$ & $\mathrm{CH}_{4}$ & $0.2 \mathrm{ppmv}$ \\
\hline madIR-D01 & Madur, & & Laser & & \\
\hline $\mathrm{CO} 2$ & SARAD & $\begin{array}{l}\text { Zgierz, Poland } \\
\text { Milton Keynes, }\end{array}$ & $\begin{array}{l}\text { Spectroscopy } \\
\text { Fourier Transform } \\
\text { Infrared }\end{array}$ & $\mathrm{CO}_{2}$ & 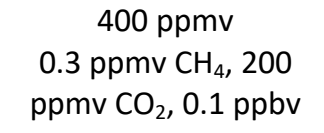 \\
\hline DX4030 & $\begin{array}{l}\text { Gasmet } \\
\text { LICOR, } \\
\text { WEST }\end{array}$ & United Kingdom & $\begin{array}{l}\text { Spectroscopy } \\
\text { Nondispersive } \\
\text { Infrared }\end{array}$ & $\mathrm{CH}_{4}, \mathrm{CO}_{2}, \mathrm{NH}_{3}$, & $\mathrm{NH}_{3}$ \\
\hline LI820 & Systems & $\begin{array}{c}\text { Pontedera, Italy } \\
\text { Dresden, }\end{array}$ & $\begin{array}{l}\text { Spectroscopy } \\
\text { Alpha }\end{array}$ & $\mathrm{CO}_{2}$ & $5 \mathrm{ppmv}$ \\
\hline RTM 2200 & SARAD & Germany & spectroscopy & $\mathrm{Rn}$ & $0 \mathrm{~Bq} / \mathrm{m}^{3}$ \\
\hline
\end{tabular}

